\title{
Okul Öncesi Eğitim Kurumlarında Kadın Yönetici Olmak: Sorunlar ve Ĕgilimler*
}

\author{
Being a Female Manager at Pre-School Education \\ Institutions: Problems and Tendencies
}

\begin{abstract}
Akif KÖSE**, Mehmet UZUN***
Öz: Bu araştırmada okul öncesi eğitim kurumlarının yöneticiliğine ilişkin okul öncesi eğitim kurumlarında görev yapan kadın yöneticilerinin görüşlerinin incelenmesi amaçlanmıştır. Araştırma nitel bir çalışma olup durum çalışması deseninde gerçekleştirilmiş̧ir. Araştırmanın çalışma grubunu Kahramanmaraş ili merkez Onikişubat ve Dulkadiroğlu İlçelerindeki bağımsız anaokullarda görev yapan 10 kadın okul yöneticisi oluşturmaktadır. Araştırmanın verileri araştırmacılar tarafindan hazırlanan yarı yapılandırılmış görüşme formu kullanılarak elde edilmiştir. Elde edilen veriler içerik analizine tabi tutulmuştur. Araştırma sonucunda; okul öncesi eğitim kurumlarında yöneticinin erkek ya da kadın olmasına yönelik katılımcı görüşlerinin bir kısmı cinsiyetin önemli olmadığı yönünde iken diğer kısmı ise yöneticinin kadın olması gerektiği şeklinde ortaya çıkmıştır. Yöneticilikte cinsiyetin önemli olmadığını düşünenlerin, yöneticiyi mesleki yetkinlik ve liderlik özellikleri açısından değerlendirdikleri görülmüştür. Yöneticinin kadın olması gerektiğini düşünenler ise yöneticiyi kadına özgü özellikler ve iletişim açısından değerlendirdikleri ortaya çıkmıştır. Kadın yöneticilerin, fiziksel düzen ve tertibi daha iyi sağlamaları, çocuklarla, anne velilerle ve çoğunluğu kadın olan okul personeliyle daha yakın iletişim kurabilmeleri okul öncesi eğitim kurumlarında yöneticinin kadın olmasının güçlü yönleri olarak görülmektedir. Okul öncesi eğitim kurumunda yöneticilik yapmak kadın yöneticilere mesleki, kişisel ve sosyal açıdan birçok dezavantaj getirmektedir. Bu dezavantajlar, yöneticilerin öğretmenlikten uzaklaşmaları, aile bireylerine ve arkadaş çevresine yeterli zaman ayıramamaları gibi dezavantajlı durumlar olarak ortaya çıkmaktadır. Ayrıca kadın yöneticilerin tamamına yakınının erkek müdür yardımcısıyla çalışmayı tercih ettikleri sonucuna ulaşııııştır. Araştırma sonunda sadece kadın ya da sadece erkek yönetici görevlendirmesinin doğuracağı dezavantajlı durumların engellenebilmesi için okul öncesi eğitim kurumlarına yönetici görevlendirmelerinde müdür veya müdür yardımcısının birinin erkek diğerinin kadın olacak şekilde görevlendirme yapılabileceği önerisi getirilmiştir.

Anahtar Kelimeler: Okul öncesi eğitim kurumu, okul yöneticisi, kadın yönetici
\end{abstract}

\begin{abstract}
In this research, it was aimed to examine the views of the women managers who were working at pre-school educational institutions, on the management of pre-school education institutions. The research is a qualitative study and it was carried out in a case study pattern. The study group of the study consisted of 10 female school managers working at independent pre-schools in Kahramanmaraş province center; in Onikişubat and Dulkadiroğlu districts. The data of the study were obtained using a semi-structured interview form prepared by the researchers. The data was analyzed by content analysis. As a result of the research; Some of the participant's views on pre-school education institutions' managers were that gender was not important; and the other part was that the manager should be female. Those who think that gender is not important in management are seen to evaluate management in terms of professional competence and leadership qualities. Those who think that the manager should be women are seen that they are evaluating the managers in terms of characteristics and communication. It is seen that at pre-school educational institutions, women managers are better able to communicate with the children, mother parents and the majority of staff who are female. Managing at pre-school education institution has many disadvantages for women managers in terms of professional, personal and social. These disadvantages are seen as the
\end{abstract}

\footnotetext{
*Bu makale 28 Eylül-1 Ekim 2017 tarihleri arasında Antalyada yapılacak olan II. Uluslararası Stratejik Araştırmalar Kongresine bildiri olarak gönderilmiş olan çalışmanın genişletilmiş halidir.

**Yrd. Doç. Dr., Kahramanmaraş Sütçü İmam Üniversitesi, Eğitim Fakültesi, Kahramanmaraş-Türkiye, e-posta: akifkose@ksu.edu.tr

***Öğretmen, Kahramanmaraş İl MEM, Kahramanmaraş-Türkiye, e-posta: mehmetuzun461@ hotmail.com
} 
manager's departure from teaching, not having enough time with family members and friends. In addition, it is found that nearly all of the female managers prefer to work with male manager assistant. At the end of the research, it has been suggested that to prevent the disadvantages of only male or only female managers, at pre-school education institutions, one of the managers or manager assistants can be appointed a male, the other is female.

Keywords: Preschool educational institutions, school administrator, female administrator

\section{Giriş}

Toplumlar, hedeflerine ulaşabilmek için, sahip oldukları insan kaynağını işleme gereği duyarlar ve bu işi okullar aracılı̆̆ıyla gerçekleştirirler. Toplum için bu denli önemli bir rolü üstlenen okulların amaçlarına ulaşabilmesi yönetimleriyle yakından ilgilidir. Yönetim, örgütün belirlenmiş amaçlarını gerçekleştirecek işleri yapmak için bir araya getirilen insanları, örgütleyip eşgüdümleyerek eyleme geçirme süreci olarak tanımlanmaktadır (Başaran, 1996). Yöneticilik ise yönetim tanımında belirtilen görevlerin etkin bir şekilde gerçekleştirilmesidir (Akar, 2006). Bir diğer ifadeyle yönetici, bir örgütün amaçlarına ulaşabilmesini sağlayan planlama, organizasyon, liderlik ve kontrol faaliyetlerinden sorumlu olan kişidir (Lewis, Goodman ve Fandt, 1995). Okul yönetiminin kapsayıcısı olan eğitim yöneticiliği ise eğitim örgütlerini, önceden belirlenmiş amaçlara ulaştırmak için eğitim örgütünün sahip olduğu insan ve madde kaynaklarını etkili bir şekilde kullanıp, eğitimin genel amaç ve ilkelerine uygun, eğitim örgütünün özel amaçları çerçevesinde belirlenen politikaları ve alınan kararları uygulamak ve yönetmektir (Taymaz, 2011).

Eğitim yönetiminin sınırlı bir alanda uygulama bulmuş şekli olan okul yönetiminin görevi, okulu amaçlarına uygun olarak yaşatmaktır. Okul yönetiminden gerçekleştirmesi beklenen görevler, okul yöneticisinin üstlendiği rollerin önemini belirten bir durumdur. Yönetime atfedilen çok yönlü tanımlar, beraberinde yöneticiye pek çok farklı alanda yetki ve sorumluluklar yüklemiş bulunmaktadır. Bu yetki ve sorumluluklar okul yönetimine değer katmakla beraber okul yönetiminin önemini de arttırmaktadır (Bursalıŏlu, 2013). Okul yönetiminin uygulayıcısı olan okul yöneticisi ise okul çalışanları arasında iletişim kurarak onları eş güdümleyen, düzenlenen bütün etkinlikleri belirlenen ölçütler çerçevesinde değerlendirerek okul örgütünü etkili ve başarılı düzeye ulaştırmaya çalışan kişidir (Başar, 1995). Okul yöneticisinin bu önemi, okul yöneticilerinin okul örgütünün kültürünü ve iklimini doğrudan etkileme özelliklerinden kaynaklanmaktadır.

Her örgüt gibi okulun da kendine özgü bir kişiliği yani havası/iklimi vardır. Gruplar ve kişiler arası ilişkilerin niteliğini ve örgütün havasını olumlu ya da olumsuz etkileyen unsurlardan biri de yönetici davranışlarıdır (Şahin, 2013). İletişime açık olması ve çalışanlarını motive etmesinin yanı sıra (Drucker, 1995), birlikte çalıştıkları insanı merkeze alan eğitim yöneticilerinden, tüm okul çalışanlarına eğitim-öğretimi sevdirme, isteklilik duyarak çalıştırma, okul kurumunu benimsetme ve okulla bütünleşmelerine olanak sağlaması beklenir (Can, 2013). Eğitim yöneticisinden beklenen, yönetimin örgütsel amaçlarını gerçekleştirmesi ve eğitim çalışanlarına yaşamı kolaylaştırabilmesidir. Bu yönetsel eylemlerin sağlanabilmesi için güçlü yönetim bilgisi, liderlik ve etkili bir iletişim becerisi gerekmektedir (Cemaloğlu, 2005).

Okul yöneticilerinin sahip olduğu bilgi, beceri ve davranışlar başta öğrenci ve öğretmenler olmak üzere, diğer okul personeli ve ebeveynler üzerinde de etkili olmaktadır. Bu durum okul yöneticilerinin belirli özelliklere sahip olmasını gerektirmektedir (Yiğit, 2016). Yönetici pozisyonunda bulunan bireylerin bu mesleği isteyerek yapmas1, yeniliklere ve yenilenmeye açık, araştırmacı olması, gerekli bilgi ve beceriye sahip, kişilik özellikleri bakımından bu pozisyona uygun, grubun yapısına yön verebilecek lider bireyler olması gerekmektedir (Vural, 2008).

Eğitim örgütleri açısından önemli bir yere sahip olan okul yöneticilerinin seçimi işi de bu bakımdan ayrı bir öneme sahiptir. Türk Milli Eğitim sisteminde okul yöneticileri öğretmenler arasından ve belirli ölçütlere göre seçilmektedir. Eğitim kurumlarına yönetici görevlendirmelerinde mevcut uygulamaya göre 22 Nisan 2017 tarihli Milli Eğitim Bakanlığına Bağlı Eğitim Kurumlarına Yönetici Görevlendirme Yönetmeliği esas alınmaktadır. Bu 
yönetmeliğe göre yönetici olarak görevlendirilecek kişilerin, bir takım genel ve özel şartları karşılaması gerekmektedir (Milli Eğitim Bakanlığı [MEB], 2017a). Mevzuat açısından bakıldığında okulun eğitim öğretim ve yönetim işlerinin planl, düzenli ve amacına uygun olarak yürütülmesinden sorumlu olan okul müdürlerinin seçiminde bir takım mesleki ölçütleri sağlamış olmaları beklenmekte ancak yönetici olarak görevlendirilecek kişilerin cinsiyeti ile ilgili herhangi bir şarta rastlanmamaktadır.

Günümüz çalışma hayatında özellikle yönetim kademesinde çalışan kadınların ve erkeklerin sayısı eşit bir dağılım göstermemektedir. Yaşanan bu durum her ne kadar ülkelerin refah düzeyiyle ilişkilendirilse de, genelde kadınların tüm örgütlerde erkeklerin gerisinde kaldıkları görülmektedir (Tunç, Ural Uslan ve Gökçe, 2015). Kadınların oranı, özellikle örgütsel hiyerarşinin üst basamaklarına doğru çıkıldıkça, belirgin olarak azalma göstermektedir (İnandı ve Tunç, 2012).

Günümüzde kadınların iş hayatında yer aldıkları gelenekselleşmiş iş alanları ve meslek grupları belirginleşmiştir. Eğitim kadınların aktif olarak yer aldığı önde gelen alanlardan biridir (Asar, 2014). Türkiye'nin de aralarında bulunduğu birçok Avrupa ülkesinde kadınların eğitim alanındaki istihdam oranlarının erkeklere göre daha yüksek olduğu görülmektedir (Eğitim, İşitselGörsel Medya ve Kültür Yürütme Ajans1 [EACEA], 2010). Milli Eğitim Bakanlığının istatistiklerine göre 2016-2017 öğretim yılı 1.dönemi itibarıyla bakanlığa bağlı resmi okullarda 480.554'ü kadın, 397.240'1 erkek olmak üzere toplam 877.794 öğretmen görev yapmaktadır (MEB, 2017b). İstatistiklere bakıldığında kadınların eğitim alanındaki istihdamı erkeklere göre yüksekken aynı durumun kadın yönetici sayısına yansımadığı görülmektedir.

Kadınların eğitim yönetiminde üst düzey yönetsel pozisyonlarda yer alamayışı uluslararası bir boyuta sahiptir. Kadınlar eğitimin, öğretim kısmında yüksek oranda yer bulurken yönetim kısmında ise tam tersi bir durum söz konusudur (Priola, 2007; İnandı, Özkan, Peker ve Atik, 2009). Avrupa ülkeleri ve Amerika Birleşik Devletleri gibi ülkelerde ilk ve orta düzey eğitim kademelerinde kadın ögretmen sayısının fazla olmasına rağmen yöneticilik yapan kadınların sayısının az olduğu görülmektedir (Özan-Boydak ve Akpınar, 2002). Ülkemizde de kadın öğretmenlerin sayısı erkek öğretmenlerden fazla olmasına rağmen 1990'lı yıllarda tüm öğretim kademelerindeki kadın okul müdürlerinin ortalaması \% 2, 8'dir (Altınışık, 1995). MEB Strateji Geliştirme Başkanlığının Şubat 2017 verilerine göre MEB bünyesinde bulunan okullarda görev yapan 28.299 okul müdürünün 2.238 'i $(\% 7,91), 1.936$ müdür başyardımcısının 115 'i $(\% 5,94), 37.042$ müdür yardımcısının ise 7.431'i (\%20,04)'ü kadındır (Kadının Statüsü Genel Müdürlüğü [KSGM], 2017). Geçmişten günümüze kadınların okul yönetimindeki oranlarına bakıldığında Bakanlığın pozitif ayrımcılık yaparak kadın yönetici oranını arttırmaya çalıştığı söylenebilir. Genel olarak tüm eğitim kademelerinde kadın yöneticilerin oranı \% 7,91 olarak görülürken bu oran okul öncesi eğitim kurumlarının özelinde daha yüksektir. Okul öncesi eğitim kurumlarında kadın yönetici sayısının diğer öğretim kademelerine göre yüksek olmasının nedeni bu eğitim kurumlarında görev yapan kadın ve erkek öğretmenlerin oranından kaynaklanmaktadır. Milli Eğitim Bakanlığının istatistiklerine göre 2016-2017 öğretim yılı 1.dönemi itibarıyla bakanlığa bağlı 2.408 resmi anaokulunda 15.449' u kadın, 1.539' u erkek olmak üzere toplam 16.988 öğretmen görev yapmaktadır (MEB, 2017b). Bağımsız anaokullarının \% 90,94' ünü kadın öğretmenler oluştururken \% 9,06' sını erkek öğretmenler oluşturmaktadır. Kadın öğretmen sayısının erkek öğretmen sayısından çok fazla olduğu okul öncesi eğitim kurumları, öğretmenliğin kadın mesleği olduğu anlayışının karşılık bulduğu en belirgin alanlardan biridir.

Öğretmenlerinin yanı sıra eğitimci olmayan okul personelinin çoğunluğunu da kadınların oluşturduğu okul öncesi eğitim kurumları yapı itibarıyla diğer eğitim kurumlarından farklıdır. Bu farklılık, bu kurumların gerçekleştirmesi gereken amaçlarından, çalışan özelliklerinden ve çocukların yaş gruplarından kaynaklanmaktadır (Büte ve Balcı, 2010). Okul öncesi eğitim kurumlarında hiyerarşi genel olarak yatay gerçekleşmekte ve bu özelliğiyle bu kurumlarda yöneticiye ulaşılabilirlik diğer eğitim kurumlarına oranla daha kolay olmaktadır. Bunun yanı sıra okul öncesi eğitim kurumlarının, öğrenci ve çalışan personel sayısı bakımından küçük birimler olması ve ebeveynlerin okulla iletişim düzeylerinin diğer eğitim basamaklarına göre daha yoğun olması bu kurumların sahip olduğu diğer önemli özellikler olarak görülmektedir. Bu kurumlardaki 
yönetsel işlevlerin gerçekleştirilebilmesi için yöneticilerin bir takım rolleri yerine getirmesi gerekir (Larkin, 1999, akt: Büte ve Balc1, 2010).

Zembat (1994) okul öncesi eğitim kurumu yöneticisinin yerine getirmesi gereken rolleri:

- Örgütün amaçlarını belirleyerek, bu amaçlara uygun örgütleme yapmak ve örgütü geliştirmek,

- Etkili yönetim anlayışıyla yönetim süreçlerinden en iyi şekilde yararlanmak,

- Değişen çevre koşullarını analiz ederek örgütü bu koşullara hazırlamak,

- Davranış bilimlerinden yararlanarak, çalışanları bilgilendirmek ve yönlendirmek,

- Sorunları tespit etmek ve uygun çözüm yolları bulmak,

- Okul aile işbirliğini sağlamak,

- Güvenilir ve saygın bir ortam oluşturmak,

- Ebeveyn ve çocuklardan gelen geri dönütleri değerlendirmek,

- Çevreye katkı sağlamak meslektaşları ile yakın ilişkide bulunmak şeklinde sıralamıştır. Yönetici rolleri kapsamında ebeveyn ve eğitimcilerin etkin olduğu sistemli bir eğitim süreci (Zembat, 1994) olarak tanımlanan okul öncesi eğitim birçok ebeveynin çocuklarını formal eğitimle tanıștırdığ 1 ilk basamaktır.

Öğrenim gören çocukların yaş gruplarının küçük olması, ebeveynlerin, özellikle annelerin, çocuklarının durumu ve okuldan beklentileriyle ilgili okul yönetimiyle sık iletişim kurmaları, bu kurumlarda çalışan personelin tamamına yakınının kadınlardan oluşması ve okul öncesi eğitim kurumlarının fiziki özelliklerinin diğer kurumlardan farklı olması nedenlerinden dolayı okul öncesi eğitim kurumlarının yönetimi önem kazanmaktadır. Ayrıca kadın yönetici oranının yüksek olduğu ender alanlardan biri olması itibariyle okul öncesi eğitim kurumlarında görev yapan kadın yöneticilerin, okul öncesi eğitim kurumlarında yöneticiliğe ilişkin görüşleri ayrı bir önem arz etmektedir. Bu araştırmadan elde edilecek sonuçların okul öncesi eğitim kurumlarında yöneticinin kadın olmasının bu okullara ve yöneticiye sağladığı olumlu (güçlï) ve olumsuz (zayıf) yönlerin bilinmesi açısından alana katkı sunaca ğı düşünülmektedir. Ayrıca okul öncesi eğitim kurumlarında yöneticilik yapmayı düşünen kadın öğretmenlere de bu yönüyle 1 şık tutacağı ümit edilmektedir. Bu bağlamda bu çalışmanın problem cümlesi "Okul öncesi eğitim kurumlarının yöneticiliğine ilişkin kadın yöneticilerin görüşleri nelerdir?" şeklinde ifade edilmiştir.

Bu doğrultuda okul öncesi eğitim kurumlarında görev yapan kadın yöneticilerin:

1. Okul öncesi eğitim kurumunda yöneticinin cinsiyetine ilişkin görüşleri nelerdir?

2. Okul öncesi eğitim kurumunda yöneticinin kadın olmasının olumlu (güçlü) yönlerine ilişkin görüşleri nelerdir?

3. Okul öncesi eğitim kurumunda yöneticinin kadın olmasının olumsuz (zayıf) yönlerine ilişkin görüşleri nelerdir?

4. Yöneticiliği tercih etme nedenlerine ilişkin görüşleri nelerdir?

5. Okul öncesi eğitim kurumunda yönetici olmanın kişiye sunduğu avantajlara ilişkin görüşleri nelerdir?

6. Okul öncesi eğitim kurumunda yönetici olmanın kişiye getirdiği dezavantajlara ilişkin görüşleri nelerdir?

7. Müdür yardımcılarının erkek ya da kadın olması tercihlerine ilişkin görüşleri nelerdir?

8. Yöneticiliğe devam edip etmemeye ilişkin görüşleri nelerdir? soruları araştırmanın alt problemlerini oluşturmaktadır.

\section{Yöntem}

Araştırmanın bu kısmında araştırmanın modeli, çalışma grubu, veri toplama aracı, verilerin toplanması, veri analizi, geçerlilik ve güvenirlik çalışmalarına yer verilmiştir. 


\section{Araştırmanın Modeli}

Çalışma, betimsel bir araştırmadır. Betimsel araştırmalar olayların, objelerin, varlıkların, kurumların, grupların ve çeşitli alanların "ne" olduğunu betimlemeyi, açıklamayı amaçlar (Kaptan, 1998). Araştırma nitel araştırma yöntemlerinden durum çalışması deseninde gerçekleştirilmiştir. Durum çalışması deseni, farklı disiplinlerde farklı şeyleri ifade etmek için kullanılır ve bir olayın yoğun bir şekilde çalışılmasıyla ilgilidir. Görüşmeler ile elde edilen verilerin derinlemesine ve boylamsal olarak incelenmesini içerir (Glesne, 2013). Durum çalışması deseninde bir duruma ilişkin etkenler bütüncül bir yaklaşımla araştırılır ve ilgili durumu nasıl etkiledikleri ve ilgili durumdan nasıl etkilendikleri üzerine odaklanılır. Bütüncül çoklu durum deseninde birden fazla kendi başına bütüncül olarak algılanabilecek durum söz konusu olup her bir durum kendi içinde bütüncül olarak ele alınır ve daha sonra birbirleriyle karşılaștırılır (Yıldırım ve Şimşek, 2013). Bu çalışmada da okul öncesi eğitim kurumlarında görev yapan kadın yöneticilerin bu kurumların yöneticiliğine ilişkin görüşlerinin bütüncül bir yaklaşımla ele alınarak derinlemesine incelenmeye çalışılması araştırmanın bütüncül çoklu durum çalışması desinine uygun olduğunu göstermektedir.

\section{Çalışma Grubu}

Araştırmanın evrenini Kahramanmaraş İli Merkez Onikişubat ve Dulkadiroğlu İlçelerindeki resmi bağımsız anaokullarında görevli kadın yöneticiler oluşturmaktadır. Kahramanmaraş İli Merkez Onikişubat İlçesinde 9, Merkez Dulkadiroğlu İlçesinde ise 11 olmak üzere toplamda 20 bağımsız anaokulu bulunmaktadır. Bu okullarda görevli 20 okul müdürünün 10'u kadın olup araştırma kapsamında bu kadın yöneticilerin tamamına ulaşıımıştır. Bu bakımdan araştırmanın evreni aynı zamanda çalışma grubunu oluşturmaktadır. Araştırmada amaçlı örnekleme yöntemlerinden tipik durum örneklemesi yöntemi kullanılmıştır. Tipik durum örneklemesindeki amaç, ortalama durumları çalışarak belirli bir alan hakkında fikir sahibi olmaktır (Yıldırım ve Şimşek, 2013).

Araştırmanın çalışma grubuna ait bazı demografik özellikler Tablo 1'de verilmiştir.

Tablo 1

Araştırma Grubunun Bazı Demografik Özellikleri

\begin{tabular}{|c|c|c|c|}
\hline Değişken & & Frekans (f) & Yüzde \% \\
\hline \multirow{6}{*}{ Yaş } & 25-30 Aras1 & 1 & 10 \\
\hline & 31-35 Aras1 & 1 & 10 \\
\hline & 36-40 Aras1 & 4 & 40 \\
\hline & 41-45 Aras1 & 1 & 10 \\
\hline & 46-50 Aras1 & 2 & 20 \\
\hline & 51 ve Üzeri & 1 & 10 \\
\hline \multirow{2}{*}{ Medeni Durum } & Evli & 7 & 70 \\
\hline & Bekâr & 3 & 30 \\
\hline \multirow{2}{*}{ Çocuk Sahibi Olma Durumu } & Evet & 9 & 90 \\
\hline & Hayır & 1 & 10 \\
\hline \multirow{4}{*}{$\begin{array}{l}\text { MEB'deki Toplam } \\
\text { Hizmet Süresi }\end{array}$} & 6-10 Y1l Aras1 & 2 & 20 \\
\hline & 11-15 Y1l Aras 1 & 2 & 20 \\
\hline & 16-20 Y1l Aras 1 & 3 & 30 \\
\hline & 21 Y1l ve Üzeri & 3 & 30 \\
\hline \multirow{3}{*}{$\begin{array}{l}\text { Yöneticilikteki Toplam } \\
\text { Hizmet Süresi }\end{array}$} & 1-5 Y1l Aras1 & 6 & 60 \\
\hline & 6-10 Y11 Aras1 & 2 & 20 \\
\hline & 11 Y1l ve Üzeri & 2 & 20 \\
\hline \multirow{4}{*}{ Eğitim Durumu } & Önlisans & 1 & 10 \\
\hline & Lisans & 5 & 50 \\
\hline & Lisansüstü & 4 & 40 \\
\hline & Toplam & 10 & 100 \\
\hline
\end{tabular}




\section{Veri Toplama}

Araştırma verileri görüşme yolu ile elde edilmiştir. Görüşmeler esnasında yarı yapılandırılmış görüşme formu kullanılmıştır. Yarı yapılandırılmış görüşme formunda kadın okul öncesi kurum yöneticilerine açık uçlu 8 soru yöneltilmiştir. Araştırmacılar tarafindan oluşturulan görüşme formundaki sorular araştırmanın amaçları göz önünde bulundurularak ve alanyazın taramasından faydalanılarak oluşturulmuştur. Görüşme formlarının asıl uygulanmasına geçmeden önce iki yöneticiyle pilot uygulama yapılmıştır. Pilot uygulamada soruların; araştırmanın amacına uygunluğu, anlaşılır ve sıralanışının uygun olup olmadığı değerlendirilmiş, değerlendirme sonucunda şekil, amaç ve kapsam yönlerinden bir sorunun görülmediği ve görüşme formunun bu haliyle asıl uygulamada kullanılabileceği kanaatine varılmıştır. Görüşme formu iki bölümden oluşmaktadır. Birinci bölümde çalışma grubuna ait demografik bilgiler ikinci bölümde ise görüşme soruları yer almaktadır. Araştırmanın çalışma grubu içerisinde yer alan kadın yöneticilere M1'den başlayarak M10'a kadar isimler verilmiştir.

\section{İslem}

Kahramanmaraş İl Milli Eğitim Müdürlügünden çalışma için gerekli izinler alındıktan sonra katılımcilarla 10.04.2017 tarihi ile 21.04.2017 tarihi arasında farkl1 gün ve saatlerde görüşmeler gerçekleştirilmiştir. Görüşme öncesinde katılımcılara çalışmanın amacı ve yapılan görüşmenin gizliliği hakkında bilgiler verilmiş, katılım için gönüllü olup olmadıkları sorulmuştur. Görüşmeler kadın yöneticilerin görev yaptıkları okullarda gerçekleştirilmiştir. Görüşmeler katılımcılarla karşılıklı konuşma şeklinde gerçekleştirilmiş ve katılımcıların yanıtları araştırmacılar tarafından formlara yazılarak kaydedilmiştir. Araştırmanın çalışma grubunda yer alan katılımcıların her biri ile yapılan görüşme ortalama 30 dakika sürmüş toplam 10 kişi ile yaklaşık 300 dakika (5 saat) süren görüşmeler yapılmıştır.

\section{Verilerin Analizi}

Katılımcılarla yapılan görüşmeler sonucunda elde edilen verilerin önce kavramsallaştırılması daha sonra da ortaya çıkan kavramlara göre mantıklı bir biçimde düzenlenmesi ve buna göre veriyi açıklayan temaların saptanmasını gerektiren içerik analizi yöntemi kullanılmıştır (Yıldırım ve Şimşek, 2013). Veriler araştırmacılar tarafından okunarak kodlamalar yapılmış, araştırmacılar tarafindan ikinci kez okuma yapılmış ve ikinci okuma sonunda bazı kodların ismi değiştirilmiştir. Oluşan kodların hangi temalar altında toplanabileceği üzerinde çalışılmış ve oluşabilecek temalar belirlenmiştir. Araştırmacılar tarafindan oluşturulan kodlar karşılaştırılmış ve bu karşılaştırma neticesinde kodların ve temaların ne olacağına ilişkin nihai karar verildikten sonra kodlamalara ilişkin frekans tabloları oluşturulmuştur.

\section{Geçerlilik ve Güvenilirlik}

Araştırmacıların araştırma sürecinde araştırmanın yöntem ve aşamalarını açık ve anlaşılır bir biçimde ifade etmesi, araştırmanın ham verilerinin başkaları tarafından incelenebilecek biçimde saklanması bu araştırmanın dış güvenirliğini sağlayan konular olarak görülmektedir. Araştırma sorularının açı bir biçimde ifade edilmesi, araştırma verilerinin soruların gerektirdiği biçimde ayrıntılı ve amaca uygun bir biçimde toplanmaya çalışılması, araştırmacılar tarafindan oluşturulan iki ayrı kodlamanın karşılaştırılması araştırmanın iç güvenirliğini sağlayan nitelikler olarak değerlendirilmektedir (Yıldırım ve Şimşek, 2013). Araştırmacılar tarafından yapılan kodlamalar birbirleri ile karşılaştırılmış ve tutarlılıkları incelenmiştir. Araştırmacıların yaptıkları kodlamalar arasındaki uyumun yüzdesini belirlemek için güvenirlik analizi gerçekleştirilmiştir. Bu işlemde Kodlayıcılar Arası Güvenirlik Yüzdesi= [Görüş Birliği/(Görüş Birliği+Görüş Ayrıllı̆gl)] formülünden (Miles ve Huberman, 1994) yararlanılmış ve güvenirliğin .72 olduğu görülmüsştür. 


\section{Bulgular}

\section{Okul Öncesi Ĕ̆itim Kurumunda Yöneticinin Cinsiyeti}

Okul öncesi eğitim kurumunda yöneticinin cinsiyetine ilişkin kadın yöneticilerin görüşlerinin analizi sonucu elde edilen temalar ve temalara ilişkin kodlar Tablo 2' de verilmiştir.

Tablo 2

Okul Öncesi Eğitim Kurumunda Yöneticinin Cinsiyeti

\begin{tabular}{|c|c|c|c|c|}
\hline \multirow{13}{*}{$\begin{array}{l}\text { Okul Öncesi Eğitim } \\
\text { Kurumunda } \\
\text { Yöneticinin } \\
\text { Cinsiyeti }\end{array}$} & \multirow{7}{*}{ Nedenler } & Yöneticinin Cinsiyeti & & Frekans \\
\hline & & Önemli Değildir & & 5 \\
\hline & & Alana hâkimiyet & & 4 \\
\hline & & İșini iyi yapması & & 2 \\
\hline & & Liderlik & & 2 \\
\hline & & İsteklilik & & 1 \\
\hline & & & Toplam & 9 \\
\hline & \multirow{6}{*}{ Nedenler } & Kadın Olmalıdır & & 5 \\
\hline & & Annelik duygusu & & 3 \\
\hline & & Daha ivi iletisim & & 3 \\
\hline & & Duvarlilık & & 2 \\
\hline & & Kadın titizliği & & 1 \\
\hline & & & Toplam & 9 \\
\hline
\end{tabular}

Tablo 2'de görüldüğü üzere görüşmeye katılan kadın yöneticilerinin yarısı okul öncesi eğitim kurumunda yöneticinin cinsiyetinin önemli olmadığını belirtirken diğer yarısı yöneticinin kadın olması gerektiğini ifade etmiştir.

Cinsiyetin önemli olmadığını belirten kadın yöneticiler yöneticilik yapacak kişinin; "alana hâkimiyet, işini iyi yapmast, liderlik ve isteklilik" konularında yeterliliğe sahip olması gerektiğini belirtmişlerdir. Alana hâkimiyet, kadın yöneticilere göre okul öncesi eğitim kurumunda yöneticilik yapabilmek için sahip olunması gereken önemli bir özellik olarak görülmektedir. Yöneticinin işini iyi yapması, liderlik özelliklerine sahip olması ve yönetim işinde istekli olması yönetimde cinsiyetin önemli olmadığıyla ilgili kadın yöneticiler tarafından belirtilen diğer hususlardır. Yöneticilerin açıklamalarına örnek olabilecek bazı alıntılar aşağıda sunulmuştur:

\footnotetext{
"Mesleklerde cinsiyet faktörü gözetmiyorum. Bu okul öncesi kurumlarında yönetici olmak içinde geçerli. Önemli olan kişinin işini iyi yapabilmesi, vizyoner olması, liderlik özelliklerine sahip olmasidir." (M1)

"Cinsiyetin herhangi bir önemi olduğunu düşünmüyorum. İşini sahiplenmesi ve alana hakim olmasl yeterli bir kriterdir.” (M4)

"Okul öncesi eğitim kurumunda yöneticinin erkek ya da kadın olmasından çok liderlik özelliklerine ve okul öncesine yönelik bakış açısına sahip olması önemlidir.” (M5)
}

Yöneticinin kadın olması gerektiğini düşünenler ise; "annelik duygusu, daha iyi iletişim duyarlılık ve kadın titizliği" konularından dolayı yöneticinin kadın olması gerektiğini ifade etmiş̧lerdir. Kadın yöneticilerin sahip oldukları annelik duygusu, kadınların velilerle daha iyi iletişime girebilmesi, özellikle anne velilerin kadın yöneticiyle rahat iletişim kurabilmesi, kadınların daha duyarlı olması ve kadınların düzen ve temizlik konusunda erkeklere göre daha detaycı olmaları okul öncesi eğitim kurumlarında yöneticinin kadın olması gerektiğini düşünen yöneticiler tarafından ifade edilen noktalar olarak görülmektedir. Yöneticilerin açıklamalarına örnek olabilecek bazı alıntılar aşağıdaki gibidir: 
"Nasıl ki bir baba ve annenin çocuğuna yaklaşımı farklı oluyorsa anaokulu yöneticisinin de kadın olması gerektiğini düşünüyorum. Çünkü kadın daha duyarlı oluyor." (MI)

"Okul öncesi eğitim kurumunda çocukların yaş grubu küçük olduğu için empati kurabiliyoruz. Tamamen idarecilik yapmıyorsun. Çok fazla mevzuata gerek yok. İnsan ilişkileri daha çok gerekiyor." (M7)

\section{Okul Öncesi Ĕ̈itim Kurumunda Yöneticinin Kadın Olmasının Olumlu (Güçlï) Yönleri}

Okul öncesi eğitim kurumunda yöneticinin kadın olmasının sağladığı olumlu (güçlü) yönlere ilişkin kadın yöneticilerin görüşlerinin analizi sonucu elde edilen temalar ve temalara ilişkin kodlar Tablo 3'te verilmiştir.

Tablo 3

Okul Öncesi Eğitim Kurumunda Yöneticinin Kadın Olmasının Olumlu (Güçlü) Yönleri

\begin{tabular}{|c|c|c|c|}
\hline Tema & Alt Temalar & Olumlu (Güçlï) Yönler & Frekans \\
\hline \multirow{17}{*}{$\begin{array}{l}\text { Okul Öncesi } \\
\text { Eğitim } \\
\text { Kurumunda } \\
\text { Yöneticinin } \\
\text { Kadın Olması }\end{array}$} & \multirow{5}{*}{$\begin{array}{l}\text { Okul } \\
\text { Açısından }\end{array}$} & Fiziksel düzen, tertip & 10 \\
\hline & & Detaycı düșünce & 4 \\
\hline & & Estetik bakış & 2 \\
\hline & & Pozitif ayrımcıllk & 2 \\
\hline & & Toplam & 18 \\
\hline & \multirow{4}{*}{$\begin{array}{l}\text { Çocuk } \\
\text { Açısından }\end{array}$} & Yakın iletişim kurabilme & 7 \\
\hline & & Anne farkındalığ 1 & 5 \\
\hline & & Toplam & 12 \\
\hline & & Anne velilerle iletişim & 10 \\
\hline & \multirow{4}{*}{$\begin{array}{l}\text { Ebeveyn } \\
\text { Açısından }\end{array}$} & İkna kabiliyeti & 1 \\
\hline & & Etkileme yeteneği & 1 \\
\hline & & Annelere rahatlık sağlaması & 1 \\
\hline & & Toplam & 13 \\
\hline & \multirow{4}{*}{$\begin{array}{l}\text { Okul } \\
\text { Personeli } \\
\text { Açısından }\end{array}$} & Sağlıklı iletişim & 8 \\
\hline & & Anlayışlılık & 3 \\
\hline & & Motive etme & 1 \\
\hline & & Toplam & 12 \\
\hline
\end{tabular}

Tablo 3'te görüldügü üzere okul öncesi eğitim kurumunda yöneticinin kadın olmasının sağladığı olumlu (güçlü) yönlerin; okul, çocuk, ebeveyn ve okul personeli açısından olmak üzere 4 alt tema altında toplandığı görülmektedir.

Yöneticinin kadın olmasının okul açısından sağladığı güçlü yönlere bakıldığında; "fiziksel düzen ve tertip, detaycı düşünce, estetik bakış ve pozitif ayrımcılık" konularının ifade edildiği görülmektedir. Fiziksel düzen ve tertip, katılımcıların tamamı tarafından yöneticinin kadın olmasının okula sağladığı en büyük avantaj olarak değerlendirilmektedir. Ayrıca kadınların daha detaycı düşünmesi, estetik bakış açısına sahip olmaları ve kadın olmanın okul işlerinin halledilmesi noktasında resmi/özel kurum ve kuruluşlarda pozitif ayrımcılık sağlaması kadın yöneticiler tarafından ifade edilen diğer güçlü yönler olarak görülmektedir. Yöneticilerin açıklamalarına örnek olabilecek bazı alıntılar aşağıda sunulmuştur:

"Kadın gözüyle bakıldığında erkeğin göremediğgi noktaları kadın görebiliyor. Bu özellik daha çok okulun fiziki özelliklerinde yani düzen ve tertip noktasında kendini gösteriyor. Ayrıca resmi kurumlarda kadına hayır denilememesinin avantajinı yaşıyorum." (MI)

"Kadın olunca isteklerin karşılanması hususunda söylemleri daha etkili oluyor. Bir kadın bir kadının ya da bir erkek bir erkeğin isteğini reddedebilirken, bir erkek bir kadının isteğini karşılayabiliyor." (M2)

"Okulun fiziki olarak düzenlenmesinde, düzen ve tertip anlaminda kadinlar daha estetik yaklaşabiliyor." (M8) 
Yöneticinin kadın olmasının çocuk açısından sağladığı güçlü yönlere bakıldığında; "yakın iletişim kurabilme ve anne farkındalı̆̆ı" hususlarının ifade edildiği görülmektedir. Hem kadın hem de anne olmalarından dolayı çocuklarla yakın iletişim kurabilme ve çocukların ihtiyaçlarını daha iyi anlayabilme kadın yöneticiler tarafından yöneticinin kadın olmasının çocuk açısından sağladığı a vantajlar olarak ifade edilmektedir. Yöneticilerin açıklamalarına örnek olabilecek bazı alıntılar şöyledir:

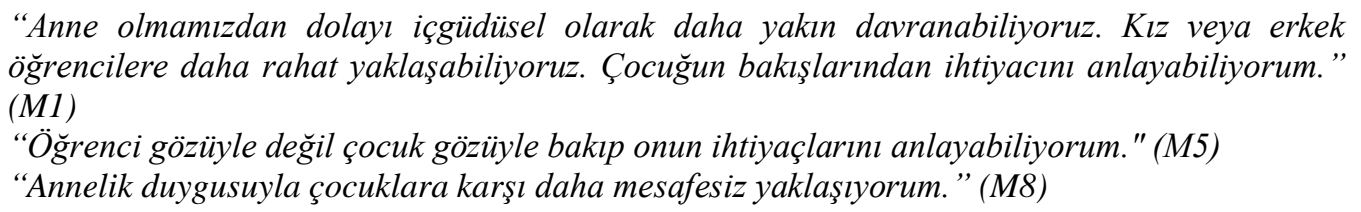
ögrencilere daha rahat yaklaşabiliyoruz. Çocuğun bakışlarından ihtiyacını anlayabiliyorum.” (M1)

"Öğrenci gözüyle değil çocuk gözüyle bakıp onun ihtiyaçlarını anlayabiliyorum." (M5)

"Annelik duygusuyla çocuklara karşı daha mesafesiz yaklaşıyorum.” (M8)

Yöneticinin kadın olmasının ebeveyn açısından sağladığı güçlü yönlere bakıldığında; "anne velilerle iletişim, ikna kabiliyeti, etkileme yeteneği ve annelere rahatlık sağlaması" konularının ifade edildiği görülmektedir. Katılımcılar okul öncesi eğitim kurumlarında çocuklarla daha çok anne velilerin ilgilendiğini belirterek annelerin düşünce ve isteklerini aktarmada kadın yöneticilerle daha rahat iletişim kurabildiklerini ifade etmişlerdir. Kadın olmanın ebeveynleri ikna etmede, etkilemede bir avantaj olduğu ve annelere okulla olan iletişim noktasında rahatlık sağladı̆̆ da kadın yöneticiler tarafından ifade edilen diğer noktalar olarak görülmektedir. Yöneticilerin açıklamalarına örnek olabilecek bazı ifadeler verilmiştir:

“Okulun bulunduğu çevre dezavantajlı ve sürekli göç alan bir bölge olduğundan annelerle çok daha rahat iletişim kurabiliyorum. Erkek idareci ya da erkek ögretmen durumunda erkekler eşlerini okula gönderme noktasında kisitlayabiliyor." (MI)

"Okul öncesinde daha çok annelerle muhatap olduğumuz için okul müdürü bayansa bizimle daha rahat iletişim kurabiliyorlar." (M8)

Yöneticinin kadın olmasının okul personeli açısından sağladığı güçlü yönlere bakıldığında; "sağlıklı iletişim, anlayışlılık ve motive etme" konularının ifade edildiği görülmektedir. Katılımcılar okul öncesi eğitim kurumlarında görev yapan öğretmenlerin ve yardımcı personelin çoğunluğunu kadınların oluşturduğunu ve bu kadın personellerin duygu, düşünce ve isteklerini ifade etmede kadın yöneticilerle daha rahat iletişim kurabildiklerini belirtmişlerdir. Kadın yöneticiler aynı cinsiyeti paylaştıkları kadın okul personeline karşı daha anlayışlı yaklaşabildiklerini ve personeli motive etme noktasında kadın olmanın avantaj sağladığını ifade etmişlerdir. Yöneticilerin konuyla ilgili bazı ifadeleri şöyledir:

"Personelin çoğunluğunun bayan olması yakınlık kurma anlamında avantaj sunuyor. Kadınlar kadınlarl daha iyi anllyor." (M2)

"Öğretmenlerin ve diğer personelin çoğunluğu bayan olduğundan iletişim noktasında daha rahat oluyorlar." (M5), (M9), (M10)

\section{Okul Öncesi Ĕ̆itim Kurumunda Yöneticinin Kadın Olmasının Olumsuz (Zayıf) Yönleri}

Okul öncesi eğitim kurumunda yöneticinin kadın olmasının getirdiği olumsuz (zayıf) yönlere iliş̧kin kadın yöneticilerin görüşlerinin analizi sonucu elde edilen temalar ve temalara ilişkin kodlar Tablo 4'te verilmiştir. 
Tablo 4

Okul Öncesi Eğitim Kurumunda Yöneticinin Kadın Olmasının Olumsuz (Zayıf) Yönleri

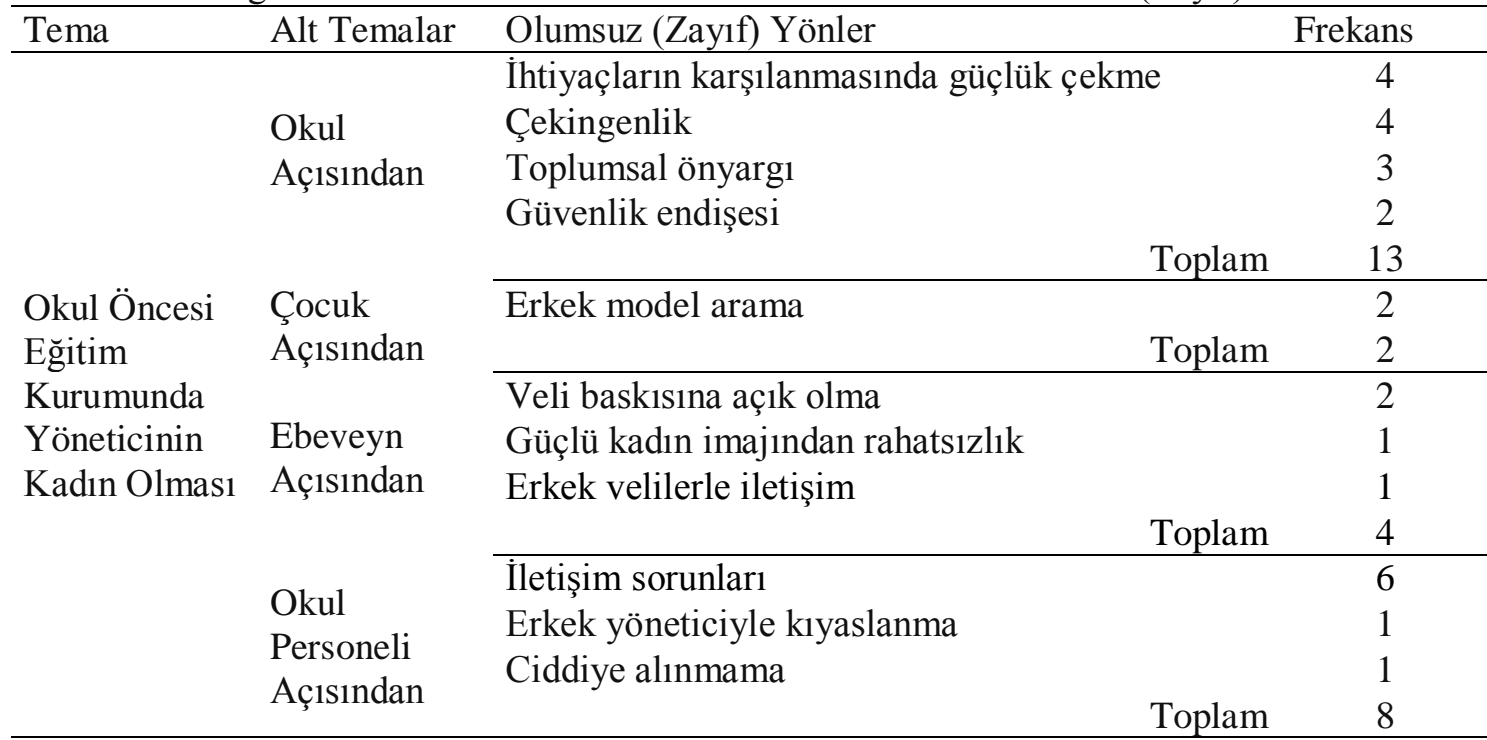

Tablo 4'te görüldügü üzere okul öncesi eğitim kurumunda yöneticinin kadın olmasının getirdiği olumsuz (zayıf) yönlerin; okul, çocuk, ebeveyn ve okul personeli açısından olmak üzere 4 alt tema altında toplandığı görülmektedir.

Yöneticinin kadın olmasının okul açısından getirdiği zayıf yönlere bakıldı̆̆ında; "ihtiyaçların karşılanmasında güçlük çekme, çekingenlik, toplumsal önyargı ve güvenlik endişesi" konularının ifade edildiği görülmektedir. Kadın yöneticiler fiziksel ihtiyaçların karşılanmasında zorlanmayı, okulla ilgili isteklerin talep edilmesinde kadın olmalarından dolayı çekingen davranmayı, toplumdaki bazı insanların kadın yöneticiye karşı olumsuz bakışını ve okulla ilgili oluşabilecek olumsuz bir durumda güvenlik endișesi yaşamalarını yöneticinin kadın olmasının okul açısından zayıf yönleri olarak görmektedirler. Yöneticilerin bu konuyla ilgili bazı görüşlerine bakıldığında:

"Erkeklerin yapacağı fiziksel işleri yapmakta zorlaniyorum. Okula yabancı biri geldiğinde tedirgin oluyorum." (M3)

"Fiziki ihtiyaçların karşılanmasında bayanlar biraz daha pasif kalabiliyor. Bayanın resmi kurumlardan bir şey istemesi durumunda olumsuz bir baklş açısı olabiliyor. Hemen yanlış anlaşılmaya müsait. Cinsiyet sizi bazı noktalarda durdurabiliyor. Yönetici algısı müdür değil, kadın müdür olarak ifade ediliyor. Kadına karşı bu noktada toplumda olumsuz bir algl var." (M5)

Yöneticinin kadın olmasının çocuk açısından getirdiği olumsuz yönlere bakıldığında; "erkek model arama" konusunun ifade edildiği görülmektedir. Bazı erkek çocuklarının erkek yönetici görme isteği ve bu isteğin karşılanaması kadın yöneticiler tarafından olumsuzluk olarak değerlendirilmektedir. Yöneticilerin açıklamalarına örnek olabilecek bazı alıntılar aşağıda sunulmuştur:

"Bazen erkek çocuklar yöneticinin erkek olmasinı istiyor." (M6)

Yöneticinin kadın olmasının ebeveyn açısından getirdiği zayıf yönlere bakıldığında; "veli baskısına açık olma, güçlü kadın imajından rahatsızlık ve erkek velilerle iletişim" hususlarının ifade edildiği görülmektedir. Katılımcılar yöneticinin kadın olmasından dolayı bazı ebeveynlerin iletişimde baskın olmaya çalışmasını, karşılarındaki güçlü kadın görüntüsünden rahatsız olmalarını ve erkek velilerle iletişim kurma noktasında bazen problem yaşamalarını olumsuzluk 
olarak görmektedirler. Yöneticilerin açıklamalarına örnek olabilecek bazı alıntılar aşağıda sunulmuştur:

"Bazı veliler iletim kurarken kadın olmamdan dolayı baskın çımaya çalışıyor. (M4)

Özellikle iletişim yerine farklı ifade ve tavirlara giren ailelerle muhatap olma noktasında kadın yöneticilik zor olabiliyor." (M6)

Yöneticinin kadın olmasının okul personeli açısından getirdiği zayıf yönlere bakıldığında; "iletişim sorunlarl, erkek yöneticiyle kıyaslanma ve ciddiye alınmama" konularının ifade edildiği görülmektedir. Okul öncesi eğitim kurumlarında çalışanların çoğunluğunu kadınların oluşturmasından dolayı personelin hemcinsleri olan okul yöneticisine kendilerini yakın hissettikleri ve bu durumun bazı personeller tarafından iletişim sınırlarının aşılmasına sebebiyet verdiği yöneticiler tarafindan dezavantaj olarak görülmektedir. Ayrıca erkek yöneticiyle kıyaslanma ve ciddiye alınmama durumu yöneticiler tarafindan olumsuzluk olarak ifade edilen diğer konular olarak görülmektedir. Yöneticilerin açıklamalarına örnek olabilecek bazı alıntılar aşağıda sunulmuştur:

"Erkek yöneticiler çok fazla sorgulamadıkları için bayan personeller zaman zaman bu durumu kullanıyor. Yönetici bayan olduğu zaman bu durumları hissedebiliyor. Bayan olduğumuz için bazen resmiyet ve samimiyet karışabiliyor." (M1)

“Bazen iletişim noktasında bayan olduğumuz için rahat olma sınırı aşılabiliyor.” (M4)

"Problemli bir personel varsa bayan idareciyi ciddiye almama, önemsememe gibi bir durum oluşabiliyor. Bayan idarecinin kullandı̆̆ algllanabiliyor." (M7)

\section{Kadın Yöneticilerin Yöneticiliği Tercih Etme Nedenleri}

Okul öncesi eğitim kurumunda görev yapan kadın yöneticilerin yöneticiliği tercih etme nedenlerine ilişkin görüşlerinin analizi sonucu elde edilen temalar ve temalara ilişkin kodlar Tablo 5'te verilmiştir.

Tablo 5

Kadın YöneticilerinYöneticiliği Tercih Etme Nedenleri

\begin{tabular}{|c|c|c|c|c|}
\hline Tema & Alt Temalar & Nedenler & & Frekans \\
\hline \multirow{10}{*}{$\begin{array}{l}\text { Yöneticiliği } \\
\text { Tercih Etme } \\
\text { Nedenleri }\end{array}$} & \multirow{6}{*}{ Mesleki } & Yönetici olma isteği & & 4 \\
\hline & & Alana katkı sağlama düşüncesi & & 2 \\
\hline & & Etki alanını genişletme isteği & & 2 \\
\hline & & Öğretmenliğin yorucu olmas1 & & 2 \\
\hline & & Mesleki doyum sağlama isteği & & 2 \\
\hline & & & Toplam & 12 \\
\hline & \multirow{4}{*}{ Kişisel } & Yönlendirilmiş olma & & 2 \\
\hline & & Lisansüstü eğitim & & 1 \\
\hline & & Tayin isteme & & 1 \\
\hline & & & Toplam & 4 \\
\hline
\end{tabular}

Tablo 5'te görüldüğü üzere okul öncesi eğitim kurumunda görev yapan kadın yöneticilerin yöneticiliği tercih etme nedenlerinin; mesleki ve kişisel nedenler olmak üzere 2 alt tema altında toplandığı görülmektedir.

Mesleki nedenler olarak; "yönetici olma isteği, alana katkı sağlama düşüncesi, etki alanını genişletme isteğ $i$, ögretmenliğin yorucu olması ve mesleki doyum să̆lama isteğ $i "$ konularının ifade edildiği görülmektedir. Kadın yöneticilerin yöneticilik yapma isteği, okul öncesi eğitime yönetici olarak katkı sağlama düşüncesi, okul öncesi öğretmenliğinin fiziksel ve zihinsel açıdan yorucu olması ve yönetici olarak yapılacak işlerden mesleki doyum sağlama 
düşüncesinden dolayı yöneticiliği tercih ettiklerini ifade etmişlerdir. Yöneticilerin açıklamalarına örnek olabilecek bazı alıntılar aşağıda sunulmuştur:

"Öğretmenlikten yeterli doyumu sağladım artık kendimi tekrarliyordum. Branşımızın çok yıpratıcı olması da yöneticiliği tercih etmemde bir etken." (MI)

"Çalıştığım alana kendimce katkı sunmak istedim. Sinlf içerisinde kalmak mesleki olarak beni tatmin etmedi. Daha fazla ögrenciye ve veliye hitap etmek istedim. ” (M4)

"Öğretmenken sadece sinif içerisinde kaliyorsunuz. İdareci olunca daha geniş bir kesime hitap firsatınız oluyor. 4+4+4'den dolayl yaş grubu düştü ve okul öncesi ögretmenliği ögrretmenlikten çok bakıcı olarak görüldü." (M7)

Kişisel nedenler olarak; "yönlendirilmiş olma, lisansüstü eğitim ve tayin isteme" konularının ifade edildiği görülmektedir. Bazı yöneticiler üst yöneticilerinin tavsiyesiyle yöneticiliğe başladığını belirtirken, birer yönetici ise lisansüstü eğitime devam etme noktasında kolaylık sağlaması ve il içi yer değiştirme nedeniyle yöneticiliği tercih ettiğini belirtmektedir. Yöneticilerin açıklamalarına örnek olabilecek bazı ifadeler aşağıdaki gibidir:

“idarecilik yapmam teklif edildi. Kendimi işin içinde buldum." (M3)

\section{Okul Öncesi Ĕ̈itim Kurumunda Yöneticiliğin Kişiye Sunduğu Avantajlar}

Okul öncesi eğitim kurumunda yöneticiliğin kişiye sunduğu avantajlara ilişkin kadın yöneticilerin görüşlerinin analizi sonucu elde edilen temalar ve temalara ilişkin kodlar Tablo 6'da verilmiştir.

Tablo 6

Yöneticiliğin Kişiye Sunduğu Avantajlar

\begin{tabular}{|c|c|c|c|c|}
\hline Tema & Alt Temalar & Avantajlar & & Frekans \\
\hline \multirow{15}{*}{$\begin{array}{l}\text { Yöneticiliğin } \\
\text { Kişiye Sunduğu } \\
\text { Avantajlar }\end{array}$} & \multirow{8}{*}{ Mesleki } & Daha geniş bir açıdan bakabilme & & 6 \\
\hline & & Mesleki doyum sağlama & & 5 \\
\hline & & Yönetim becerisi kazanma & & 5 \\
\hline & & Statï & & 2 \\
\hline & & İlgi alanlarının değişmesi & & 1 \\
\hline & & Problem çözme becerisi kazanma & & 1 \\
\hline & & & Toplam & 20 \\
\hline & & Mutluluk & & 4 \\
\hline & \multirow{4}{*}{ Kişisel } & Hareketli bir yaşam & & 1 \\
\hline & & Güçlü yönleri farketme & & 1 \\
\hline & & Daha fazla sorumluluk sahibi olma & & 1 \\
\hline & & Tecrübe kazanma & & 1 \\
\hline & \multirow{3}{*}{ Sosyal } & & Toplam & 8 \\
\hline & & Sosyal çevrenin genişlemesi & & 10 \\
\hline & & & Toplam & 10 \\
\hline
\end{tabular}

Tablo 6' da görüldüğü üzere okul öncesi eğitim kurumunda yöneticiliğin kişiye sunduğu avantajların; mesleki, kişisel ve sosyal avantaj olmak üzere 3 tema altında toplandığ görülmektedir.

Okul öncesi eğitim kurumunda yönetici olmanın kişiye sunduğu mesleki avantajlara bakıldığında; "daha geniş bir açıdan bakabilme, mesleki doyum sağlama, yönetim becerisi kazanma, statü, ilgi alanlarının değişmesi ve problem çözme becerisi kazanma" konularının kadın yöneticiler tarafından ifade edildiği görülmektedir. Yöneticiliğin, kişiye olayları daha geniş bir açıdan görebilme firsatı vermesi, yönetsel olarak gerçekleştirilen işlerin mesleki doyum sağlaması, yöneticiliğin yönetime dair bilgi, beceri ve tecrübenin artmasını sağlaması, mesleki olarak statü kazandırması, mesleki olarak kişinin ilgi alanlarını değiştirmesi ve problem çözme 
becerisi sağlaması kadın yöneticiler tarafından ifade edilen avantajlar olduğu görülmektedir. Yöneticilerin açıklamalarına örnek olabilecek bazı ifadeleri aşağıdaki gibidir:

“Öğretmenken sadece sınıfından haberdarsın. Anasınıfı ögrretmeniyken şimdi yöneticilik yapıyorum. Vizyonumun genişlediğini düşünüyor, problem çözme becerileri ve kriz yönetimi noktasında kendimi geliştirdiğimi düşünüyorum." (M1)

"Kendimi daha iyi hissettim. Yaptı̆̆ım işlerden mutlu oldum. Aldı̆̆ım eğitimin hakkını verebilme firsatın yakaladım." (M4)

"Sadece eğitici değilsiniz bir işletme yönetiyorsunuz aynı zamanda. Vizyonunuz genişliyor. Ögretmenken fark edemediğiniz yönleriniz ortaya çılkyor bu süreçte. Öğretmenken sadece sınıfin içini görebiliyordum. Yöneticilik okulun ihata duvarına kadar görmenizi sağllyor.” (M5)

Okul öncesi eğitim kurumunda yönetici olmanın kişiye sunduğu kişisel avantajlara bakıldığında; "mutluluk, hareketli bir yaşam, güçlü yönleri fark etme, daha fazla sorumluluk sahibi olma ve tecrübe kazanma" konularının kadın yöneticiler tarafından ifade edildiği görülmektedir. Kadın yöneticiler yöneticilik yapmaktan dolayı mutlu olduklarını belirtmektedirler. Bir yönetici ise yöneticiliğin yaşantısını hareketlendirdiğini, güçlü yönlerini fark etmesine olanak sağladığını, sorumluluk duygusunu arttırdığını ve kendisine tecrübe kazandırdığını ifade etmiştir. Yöneticilerin açıklamalarına örnek olabilecek bazı ifadelerine bakıldığında:

“Ÿ̈neticilik yapmak kendimi iyi hissettiriyor. Mutlu oluyorum.” (M7), (M10)

Okul öncesi eğitim kurumunda yönetici olmanın kişiye sunduğu sosyal avantajlara bakıldığında; "sosyal çevrenin genişlemesi" konusunun kadın yöneticilerin tamamı tarafından ifade edildiği görülmektedir. Kadın yöneticiler yöneticilik sayesinde farklı insanlarla tanışma firsatı bulduklarını ve bunun sosyal çevrelerini genişlettiğini ifade etmişlerdir. Yöneticilerin açıklamalarına örnek olabilecek bazı alıntılar şöyledir:

"Farklı idareci gruplarıla, farklı kurumlardaki insanlarla ve birçok veli ile tanışma firsatı buldum. Sosyal çevrem genişledi.” (M8)

"Yönetici olunca muhatap olduğunuz kesim genişliyor. Sinıf içerisinde sadece kendi velilerinizle muhatap olurken yöneticiyken tüm okul velileriyle muhatap oluyorsunuz.” (M9)

\section{Okul Öncesi Ĕ̆itim Kurumunda Yöneticiliğin Kişiye Getirdiği Dezavantajlar}

Okul öncesi eğitim kurumunda yöneticiliğin kişiye getirdiği dezavantajlara ilişkin kadın yöneticilerin görüşlerinin analizi sonucu elde edilen temalar ve temalara ilişkin kodlar Tablo 7 'de verilmiştir.

Tablo 7

Yöneticiliğin Kişiye Getirdiği Dezavantajlar

\begin{tabular}{|c|c|c|c|}
\hline Tema & Alt Temalar & Dezavantajlar & Frekans \\
\hline \multirow{9}{*}{$\begin{array}{l}\text { Yöneticiliğin } \\
\text { Kişiye } \\
\text { Getirdiği } \\
\text { Dezavantajlar }\end{array}$} & \multirow{4}{*}{ Mesleki } & Öğretmenlikten uzaklaşma & 3 \\
\hline & & Alan dışı işlerle uğraşma (mali vb.) & 1 \\
\hline & & Toplam & 4 \\
\hline & & Aileye zaman ayıramama & 7 \\
\hline & \multirow{3}{*}{ Kişisel } & Özel havatı kisitlama & 2 \\
\hline & & Yorgunluk hissi & 2 \\
\hline & & Toplam & 11 \\
\hline & \multirow[t]{2}{*}{ Sosyal } & Akraba ve arkadaş çevresinden uzaklaşma & 6 \\
\hline & & Toplam & 6 \\
\hline
\end{tabular}


Tablo 7' ye bakıldığında okul öncesi eğitim kurumunda yöneticiliğin kişiye getirdiği dezavantajların; mesleki, kişisel ve sosyal dezavantaj olmak üzere 3 alt tema altında toplandığ görülmektedir.

Okul öncesi eğitim kurumunda yönetici olmanın kişiye getirdiği mesleki dezavantajlara bakıldığında; "öğretmenlikten uzaklaşma ve alan dışı işlerle uğraşma" konularının kadın yöneticiler tarafindan ifade edildiği görülmektedir. Öğretmenlikten uzaklaşma, kadın yöneticilerin bazıları tarafından yöneticiliğin kişiye getirdiği mesleki bir dezavantaj olarak görülmektedir. Bir yönetici ise mâli iş ve işlemlerle uğraşmayı mesleki dezavantaj olarak düşünmektedir. Yöneticilerin açıklamalarına örnek olabilecek bazı alıntılar aşağıda sunulmuştur:

“Çocuklarla yine haşır neşirim ama sınıftaki enerjiyi hissedemiyorum." (M1)

“Tekrar öğretmenliğe dönersem yapabilir miyim diye endişelerim var. ” (M7)

Okul öncesi eğitim kurumunda yönetici olmanın kişiye sunduğu kişisel dezavantajlara bakıldığında; "aileye zaman ayıramama, özel hayatı kısıtlama ve yorgunluk hissi" konularının kadın yöneticiler tarafından ifade edildiği görülmektedir. Kadın yöneticilerinin çoğunluğu ailelerine yeterli zaman ayıramamayı en büyük dezavantaj olarak görmektedir. Ayrıca yöneticiliğin kişinin özel hayatını sınırlandırması ve gün boyu çalışmanın verdiği fiziksel ve zihinsel yorgunluk bazı yöneticiler tarafindan olumsuz yönler olarak ifade edilmektedir. Yöneticilerin açıklamalarına örnek olabilecek bazı alıntılar aşağıda sunulmuştur:

"Çok fedakârlık isteyen bir iş olduğu için ailemi ihmal ettim. Geçmişte çalıştığım bir okulun adı Senem Ayşe Anaokuluydu. Kızım bana bir gün: -Benim adım Senem Ayşe olsa benimle daha çok ilgilenirdin- demişti. Buna çok üzülmüştüm." (M2)

"Uzun süre okulda kalıyorum. Hem anne hem de bir eşim. Onlara fazla vakit ayıramıyorum." (M4)

Kendime ve aileme ayırdı̆̆ım özel zaman azaldı." (M8)

Okul öncesi eğitim kurumunda yönetici olmanın kişiye sunduğu sosyal dezavantajlara bakıldığında; "akraba ve arkadaş çevresinden uzaklaşma" konusunun kadın yöneticilerin çoğunluğu tarafından ifade edildiği görülmektedir. Kadın yöneticiler yöneticilik yapmanın akrabalara ve arkadaşlara ayrılan zamanı azalttığını ifade etmişlerdir. Yöneticiler bu konuyla ilgili olarak şunları ifade etmişlerdir:

"Okulda kaldığınız sürenin uzun olması ve sorumluluklarınızın çok olması nedeniyle akraba ve arkadaşlarım ikinci planda kalabiliyor." (M5)

"Akrabalarıma ve arkadaşlarıma vakit ayıramaz oldum." (M3,(M7),(M9),(M10)

\section{Müdür Yardımcısının Erkek ya da Kadın Olması Tercihi}

Okul öncesi eğitim kurumunda görev yapan kadın yöneticilerin, müdür yardımcılarının erkek ya da kadın olması tercihine iliş̧kin görüşlerinin analizi sonucu elde edilen temalar ve temalara ilişkin kodlar Tablo 8'de verilmiştir.

Tablo 8

Müdür Yardımcısının Erkek ya da Kadın Olması Tercihi

\begin{tabular}{|c|c|c|c|}
\hline \multirow{8}{*}{$\begin{array}{l}\text { Müdür } \\
\text { Yardımcısının } \\
\text { Erkek ya da } \\
\text { Kadın Olması } \\
\text { Tercihi }\end{array}$} & & Yardımcının Cinsiyeti & Frekans \\
\hline & & Erkek olmasinı tercih ederim & 9 \\
\hline & & Erkeğin ön planda olması gereken durumlar & 5 \\
\hline & & Farklı bir bakış açısı & 4 \\
\hline & Nedenler & Denge sağlaması & 2 \\
\hline & & Güvenlik & 2 \\
\hline & & Kadınların izin ihtiyaçlarının oluşması & 1 \\
\hline & & Toplam & 14 \\
\hline
\end{tabular}




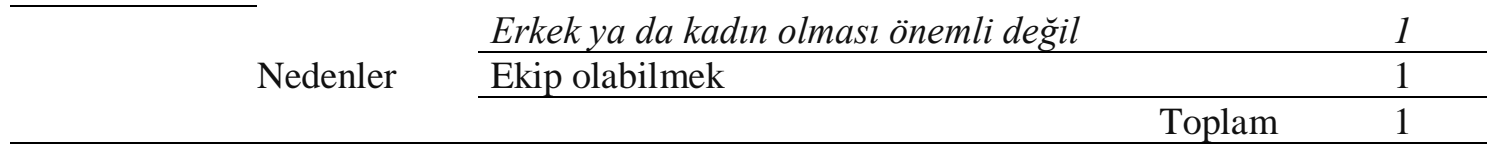

Tablo 8'de görüldüğü üzere görüșmeye katılan 10 kadın yöneticiden 9'u müdür yardımcısının erkek olmasını tercih ederken sadece 1 tanesi cinsiyetin önemli olmadığını belirtmektedir.

Müdür yardımcısının erkek olmasını tercih eden yöneticilerin görüşleri inc elendiğinde; "erkeğin ön planda olması gereken durumlar, farklı bir bakış açısl, denge sağlaması, güvenlik ve kadınların izin ihtiyaçlarının oluşması" hususlarının ifade edildiği görülmektedir. Kadın yöneticiler fiziksel güç isteyen işlerin takibi ve çözümlenmesi, okula gelen yabancıların karşılanması ve acil durumlara müdahale gibi erkeğin ön planda olması gereken durumlar için yardımcılarının erkek olmasını tercih ettiklerini ifade etmişlerdir. Çalışanların çoğunluğunu kadınların oluşturduğu bir okul öncesi eğitim kurumunda erkeğin farklı bir bakış açısı kazandıracağı da kadın yöneticiler tarafından bir tercih sebebi olarak düşünülmektedir. Yine kadın çalışanların çok olduğu okul ortamında erkeğin denge unsuru olduğu, erkeğin varlığının kadın yöneticiye ve kadın personellere kendilerini güvende hissetmelerini sağladığı ifade edilen diğer nedenler olarak görülmektedir. Ayrıca kadınların doğum, çocuklarının hastalanması vb. sebeplerden dolayı çalışmada süreklilik sağlayamayacağ tercihinin erkek olmasının nedeni olarak gösterilmektedir. Yöneticilerin açıklamalarına örnek olabilecek bazı alıntılar aşağıda sunulmuştur:

"Olaylara sürekli olarak kadın gözüyle bakmamak için erkek olmasını tercih ederim. Çalışanların çoğunluğu kadın olduğundan dengeleyebilmek adına erkeğin olması gerekli. Erkek olunca yalnız olmadığını hissediyorsun. Kendini daha güçlü hissediyorsun.” (M1)

"Okulun fiziki işlerinin, alış-veriş işlerinin halledilmesi noktasında erkek olması lazım. Erkekler esnaflarla daha rahat iletişim kurabiliyorlar ya da istedikleri yerlere daha rahat girip çıabiliyorlar. Olaylara farklı bir gözle bakabiliyorlar." (M5)

"Bayan olduğum için kendimi daha korunması hissediyorum. Erkeğin okulda olması bana güven veriyor. Acil bir durum olsa erkek müdahale edebiliyor.” (M8)

Yardımcının cinsiyetinin önemli olmadığını belirten bir yönetici ise neden olarak "ekip olabilmek" konusu ifade etmiştir. Yönetici açıklamasını yansıtan alıntı aşağıda sunulmuştur:

“Bu konuda cinsiyetin önemli olmadığını düşünüyorum. Önemli olan okulda uyum içinde çalışabilmek. ” (M6)

\section{Yöneticiliğe Devam Edip Etmeme Düşüncesi}

Okul öncesi eğitim kurumlarında görev yapan kadın yöneticilerin yöneticiliğe devam edip etmemeye ilişkin görüşlerinin analizi sonucu elde edilen temalar ve temalara ilişkin kodlar Tablo 9'da verilmiştir.

Tablo 9

Yöneticiliğe Devam Edip Etmeme Düşüncesi

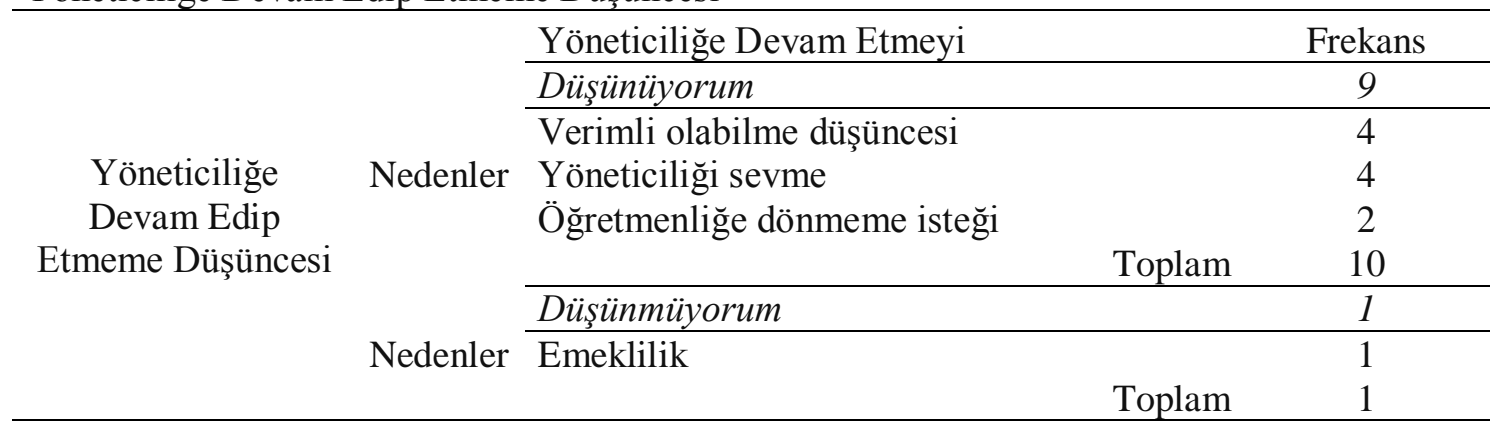


Tablo 9 incelendiğinde kendileriyle görüşme yapılan 10 kadın yöneticiden 9'u yöneticiliğe devam etmeyi düşünürken bir yöneticinin devam etmeyi düşünmediği görülmektedir.

Yöneticiliğe devam etmeyi düşünen yöneticilerin görüşleri incelendiğinde; "verimli olabilme düşüncesi, yöneticiliği sevme ve ögretmenliğe dönmeme isteği" hususlarının olduğu görülmektedir. Kadın yöneticilerin alana ve çalıştıkları kurumlara katkı sağlama, yöneticilik yapmayı sevme ve tekrardan öğretmenlik yapmayı istememe düşüncelerinden dolayı yöneticiliğe devam etmeyi düşündükleri görülmektedir. Yöneticilerin açılamalarına örnek olabilecek bir takım ifadeleri aşağıda sunulmuş̧tur:

"Artık belirli bir noktaya geldim. Tekrardan öğretmenliğe dönmek istemiyorum. (M3)

Bana kalırsa elimden geldiğince, kendimi verimli, başarıll gördügüm sürece idareci olarak eğitime katkl sağlamayı düşünürüm.” (M4)

"Ne kadar dezavantajll yönleri olsa da bu işi yapmaktan hoşlaniyorum." (M5)

Yöneticiliğe devam etmeyi düşünmeyen yönetici görüşü incelendiğinde; "emeklilik" konusunun ifade edildiği görülmektedir. Kadın yöneticilerden sadece biri kısa vadede emekli olmayı düşündüğünden dolayı yöneticiliğe devam etmeyeceğini ifade etmiştir.

\section{Sonuç, Tartışma}

$\mathrm{Bu}$ araştırmada okul öncesi eğitim kurumlarında kadın yönetici olmaya ilişkin bağımsız anaokullarında görev yapan kadın yöneticilerin görüşleri incelenmiştir. Araştırmanın sonuçları araştırma soruları altında ayrı ayrı verilerek tartışma yapılmıştır.

\section{Okul Öncesi Ĕ̈itim Kurumunda Yöneticinin Cinsiyeti}

Araştırma sonucunda okul öncesi eğitim kurumunda yöneticinin cinsiyetine yönelik kadın yönetici görüşlerinin iki başlık altında toplandığı ortaya çıkmıştır. Kadın yöneticilerin yarısı bu kurumlarda görev yapacak yöneticinin, cinsiyetinin önemli olmadığını belirtirken diğer yarısı kadın olması gerektiğini ifade etmiştir. Cinsiyetinin önemli olmadığını düşünenlerin, yöneticiyi mesleki yetkinlik ve liderlik özellikleri açısından değerlendirdiği, kadın olması gerektiğini düşünenlerin ise kadına özgü özellikler ve iletişim odaklı değerlendirdiği ortaya çıkmıştır.

Okul öncesi eğitim kurumunda yöneticilik yapacak kişinin okul öncesi eğitim alanına hâkim olması, işini iyi yapması, liderlik özelliklerine sahip olması ve istekli olması cinsiyetinin önemli olmadığını düşünen yöneticiler tarafindan ifade edilen konulardır. Türk milli eğitim sisteminde çalışan öğretmen ve yöneticilere göre, yöneticilikte cinsiyet faktörü önemli bulunmamakta, yöneticinin kadın ya da erkek olmas1 herhangi bir sorun olarak değerlendirilmemektedir. Eğitim çalışanları için önemli olan yöneticinin davranışlarıdır. Yönetici; anlayışlı, objektif ve adil olmalı, insan ilişkilerine ve katılıma önem vermeli, vizyoner yöneticilik özellikleri göstermeli, düşüncelerini çevresiyle paylaşmalı (Can, 2008), liderlik özelliklerine sahip olmalı, insanları peşinden sürükleyebilmeli ve işine gönül vermelidir (Aktepe, 2014). Mesleki yeterlilik tüm yönetim alanlarında yöneticinin sahip olması gereken bir durumdur. Bulut ve Bakan'ın (2005) araştırmalarında katılımcıların tamamına yakını yöneticileri başarılı k1lan en önemli unsurlardan biri olarak yöneticinin uzmanlık gücünü ifade etmişlerdir. Susmak ve Hacıfazlığlu'nun (2013) araştırmasında ise katılımcıların tamamı okul öncesi eğitim kurumlarında yönetici olarak görevlendirilecek kişilerin mesleki deneyimleri ve yeterliklerine bakılması gerektiğini düşündükleri sonucuna ulaşılmıştır. Farklı araştırmalara bakıldığında yöneticinin mesleki yeterliğe ve liderlik özelliklerine sahip olması, işini isteyerek yapması ve çağdaş yöneticilik özellikleri göstermesi gerektiği sonuçlarının bu araştırmanın sonuçlarıyla örtüştüğ̈̈ görülmektedir.

Okul öncesi eğitim kurumunda yöneticinin kadın olması gerektiğini düşünenler ise gerekçe olarak kadınların sahip oldukları annelik duygusu, kadınların duyarlı olması, anne velilerin kadın yöneticilerle daha rahat iletişim kurabilmeleri, kadınların titiz olması ve kadınların iletişim becerilerinin daha iyi olması hususlarını belirtmişlerdir. Annelik duygusu kadınlara görevleri itibarıyla aldıkları kararlarda ve insanlar ile olan ilişkilerinde bir çocukla ilgileniyormuş 
gibi sorumluluk almaları gerektiğini hissettirdiğinden (Kertész ve Kravetz 2011), kadın yöneticiler, annelik sıfatını yöneticiliğe katkı sunan (Korkmaz-Moralığlu, 2010) ve liderlik vasıflarını geliştirici bir faktör olarak görmektedirler (Çelikesir-Ünal, 2015). Yapılan araştırmalarda kadın yöneticilerin daha esnek ve demokratik tavırlar gösterebildikleri, işlerinde daha düzenli, titiz, ölçülü, ciddi ve detaycı bir anlayış benimsedikleri (Çelikten ve Yeni, 2004; Korkmaz-Moralıoğlu, 2010; Wu, 2006), çalışma hayatında iletişime ve insan ilişkilerine çok önem verdikleri (Baştuğ ve Çelik, 2011; Baytun ve Özerem, 2013; Çelikten, 2004; Eagly ve Johnson, 1990; Korkmaz-Moralıŏlu, 2010; Turan ve Ebiçlioğlu, 2002), okulda çok yönlü bir iletişim aği oluşturabildikleri (Çelikesir-Ünal, 2015) ve etkin bir iletişim gerçekleştirmede daha başarılı oldukları görülmektedir (Çelikten, 2005; Karc1, 2012). Bu araştırmalarda kadınların; sahip oldukları annelik sıfatının yöneticiliğe katkı sunduğu, detaycı yaklaşım benimsedikleri, insan ilişkilerine önem verdiklerive iletişim becerileri noktasında başarılı oldukları ortaya çıkmıştır. Bu sonuçların bu araştırmanın sonuçlarıyla örtüştüğü ifade edilebilir.

Okul öncesi eğitim kurumlarının sahip olduğu madde ve insan kaynakları düşünüldüğünde bu kurumların yöneticilerinin kadın olmasının yönetim noktasında avantaj sağlayabileceği söylenebilir. Ancak cinsiyetin etkili bir yönetim anlayışına sahip olmada tek başına belirleyici bir unsur olamayacağı da açıktır. Liderlik özelliklerine sahip olma, çağdaş yönetim anlayışı sergileme ve yeterli mesleki becerilere sahip olma gibi birçok etkenin etkili yönetim anlayışında belirleyici unsurlar olabileceği ifade edilebilir.

\section{Okul Öncesi Eğitim Kurumunda Yöneticinin Kadın Olmasının Olumlu (Güçlï) Yönleri}

Araştırma sonucunda okul öncesi eğitim kurumunda yöneticinin kadın olmasının okul, çocuk, ebeveyn ve okul personeli açısından birçok olumlu (güçlü) yön sağladığı sonucuna ulaşılmıştır. Kadın yöneticilerin bu güçlü yönleri daha çok, fiziki ortamın düzenlenmesi, kişiler arası ilişkiler ve iletişim odaklı değerlendirdiği görülmektedir.

Fiziksel düzen ve tertibin sağlanması, okul öncesi eğitim kurumunda yöneticinin kadın olmasının okula sağladığı güçlü bir yön olarak ortaya çıkmıştır. Ebevynler çocuklarını bir eğitim kurumuna vermeden önce o kurumun eğitim programından çok fiziki özelliklerine dikkat etmektedirler. Okulun fiziksel özelliklerini temel alırlarken, anaokulunun temiz, düzenli (AktaşArnas, 2002), sağlıklı ve güvenli olmasına önem vermektedirler (Foot ve diğerleri, 2000; Sevinç, 2006; Şimşek ve İvrendi, 2014). Milli Eğitim Bakanlığı ve Sağlık Bakanlığı arasında imzalanan protokol çerçevesinde Milli Eğitim Bakanlığı'na bağlı örgün ve yaygın eğitim kurumlarının temizlik ve hijyen konusunda teşvik edilmesi, okul sağlığının daha iyi düzeye çıkarılması amacıyla, başvurulması ve belirli kriterleri karşılamaları durumunda okullara Beyaz Bayrak verilmektedir. Araştırma kapsamında kadın yöneticilerin görev yaptığı 6 anaokulunun Beyaz Bayrak sahibi olması, 2 tanesinin ise başvuru sürecinde bulunmasının, ebeveynlerin fiziksel düzen ve temizliğe yönelik beklentilerini karşılar nitelikte bir durum olduğu söylenebilir.

Kadın yöneticilerin anne olmalarından dolayı çocuklarla yakın iletişim kurabilmeleri ve çocukların ihtiyaçlarını daha iyi anlayabilmeleri, yöneticinin kadın olmasının çocuk açısından sağladığ güçlü yönler olarak ortaya çıkmıştır. Duygusal derinliğe sahip olma ve empati kurabilme kadın eğitimcilerin öğrenciler ve velileri ile daha kolay iletişim kurmasındaki temel etmenlerden biri olarak görülmektedir (Günsel, Köroğlu ve Demirci, 2015). Sezer'e (2006) göre kadın yöneticiler öğrencilere annelik duygusuyla yaklaşıp sorunlarıyla ilgilenmekte ve çocuklarla kolay ilişkiler kurabilmektedir.

Okul öncesi eğitimde çocuklarla daha çok annelerin ilgilenmesinden dolayı anne velilerin kadın yöneticiyle daha rahat iletişim kurabilmeleri, yöneticinin kadın olmasının ebeveyn açısından sağladığı en güçlü yön olarak ortaya çıkmıştır. Çalışmayan anneler okulla daha sık iletişim kurmak için zaman ayırabilmekte (Şimşek ve İvrendi, 2014) ve genel olarak bütün anneler çocuklarının durumu ve eğitimi ile yakından ilgilenmektedir (Sevinç, 2006). Okul öncesi eğitim kurumlarında ebeveynler, yönetici ve öğretmenlerle iletişim konusuna önem vermektedir (Lindner, 2004). Kadın yöneticiler; öğretmen, öğrenci, veli, meslektaş ve diğer tüm okul toplumuyla erkek yöneticilere oranla daha fazla iletişim kurmaktadırlar (Ağıroğlu-Bakır, Uğurlu, 
Köybaşı ve Özyazıcı, 2017; Altınışık, 1995; Büte ve Balcı, 2010; Growe ve Montgomory, 2001). Farklı araştırma sonuçlarının bu araştırmanın sonucunu desteklediği söylenebilir.

Okul öncesi eğitim kurumlarında öğretmenlerin ve diğer okul personelinin çoğunluğunu kadınlar oluşturmaktadır. Öğretmenlerin ve diğer okul personelinin hemcinsleri olan kadın yöneticiyle iletişim kurmakta rahatlık yaşaması ve aynı cinsiyeti paylaştıkları için yöneticinin personele daha anlayışı yaklaşabilmesi, yöneticinin kadın olmasının okul personeli açısından sağladığ güçlü yönler olarak ortaya çıkmıştır. İletişim sürecinin işleyiş̧i ile ilgili anaokulu yöneticileri, bünyesinde anasınıfi bulunduran ilkokul ve ortaokul yöneticilerine göre öğretmenlerle daha fazla iletişim kurma şanslarının olması ve yönetim sorumluluklarının daha az olmasından dolayı iletişim sürecini daha etkin olarak kullanabilmektedir (Ebabil, 2015). Bunun yanı sıra bağımsız anaokullarında iletişimin daha çok informal yollarla gerçekleştiği söylenebilir. Aile ortamı olarak görülen okul ortamında ilişkilerin samimi, karşılıklı saygı çerçevesinde ve seviyeli olduğu, yardımlaşmanın ve fikir alış verişinin yoğun olarak yaşandığ 1 ifade edilmektedir (Büte ve Balcı, 2010). İletişim ikliminin olumlu olmasının nedeni, bu okullarda görev yapan gerek öğretmenlerin gerekse yöneticilerin daha çok kadın olması, bundan dolayı da örgüt ikliminin daha yakın, sıcak, samimi, içten, saygıll, destekleyici ve güven verici bir iletişimi mümkün kılması sonucu, öğretmenlerin yöneticilerinin kişisel özelliklerini daha yakından tanıma olanağı sağlamış olabilir (Öztürk ve Zembat, 2015). Yapılan araştırmalarda kadın yöneticilerin, kadın öğretmenlerle aynı cinsiyeti paylaşmalarından dolayı birbirlerini daha iyi anlayabilmeleri (Sezer, 2006), sezgilerinin kuvvetli olması ve duygusal olmalarından dolayı başkalarının duygularını fark etmeleri ve sorunlarıyla ilgilenmeleri avantaj olarak görülmektedir (Bayrak ve Mohan, 2001; Byron, 2007; Çelikesir-Ünal, 2015; Gökalp, 2008). Özdil-Sağ'ın (2010) araştırmasında kadın yöneticiler, öğretmenlerin çoğunlukla psikolojik ihtiyaçlarını karşılamaya çalışmakta, sıcak davranma, güzel sözler söyleme, tebrik etme ve övme gibi manevi ödülleri sıkça kullanmaktadırlar. Buna karşılık kadın personeller kadın yöneticiyle çalışmaktan mutlu olmakta ve olumlu tutum sergilemektedirler (Çalık, Koşar ve Dağlı, 2012; Baştuğ ve Çelik, 2011; Korkmaz-Moralıŏlu, 2010).

$\mathrm{Bu}$ araştırmanın sonuçlarında olduğu gibi yapılan pek çok araştırmada kadın yöneticilerin fiziksel düzenin sağlanması, çocuk ve yetişkinlerle kurulan insan ilişkileri ve iletişim konusuna önem verdiği görülmektedir. Okul öncesi eğitim kurumları özelinde düşünüldüğünde bu kurumların sahip oldukları fiziksel özellikler, öğrenci yaş guruplarının küçük olması, çocuklarla daha çok annelerin ilgilenmesi, öğretmenlerin ve eğitimci olmayan diğer okul personelinin tamamına yakınını kadınların oluşturması gibi farklılıkların araştırma sonuçlarının ortaya çıkmasında etkili olduğu söylenebilir.

\section{Okul Öncesi Ĕ̆itim Kurumunda Yöneticinin Kadın Olmasının Olumsuz (Zayıf) Yönleri}

Araştırma sonucunda okul öncesi eğitim kurumunda yöneticinin kadın olmasının okul, ebeveyn ve okul personeli açısından bazı zayıf yönlerinin bulunduğu sonucuna ulaşılmıştır. Kadın yöneticilerin bu zayıf yönleri; işlerin takibinin yapılmasında ve ihtiyaçların karşılanmasında zorlanma, toplumsal önyargı, kişiler arası ilişkiler ve iletişim kaynaklı olumsuzluklar olarak değerlendirdiği görülmektedir.

İhtiyaçların karşılanmasında güçlük çekme, çekingenlik, toplumsal önyargı ve güvenlik endişesi okul öncesi eğitim kurumunda yöneticinin kadın olmasının okul açısından zayıf yönleri olarak ortaya çıkmıştır. Bu durumun, okul öncesi eğitim kurumlarında yapılması gerekli olan iş ve işlemlerin genelde erkek okul yöneticileri tarafindan yapılması gerekli olan iş ve işlemler olduğu yönünde toplumsal bir algıdan kaynaklandığı ifade edilebilir. Türkiye koşullarında okulların pek çok sorununun bulunması, okul içi ve okul dış1 işlemlerin ve sorunların izlenmesinin mesai haricinde de çalışmayı gerektirmesi (çevreyle ve yönetimle ilişkiler, yapım ve onarım işleri, okul derneği ve velilerle ilişkiler vb.) bayanlar için engel teşkil etmektedir (Can, 2008). Ayrıca kadınlar için öğretmenliğin yöneticilikten daha uygun görülmesi, daha fazla kişiyle muhatap olmanın ve kadınların ön planda yer almasının uygun görülmemesi gibi (Ağıroğlu-Bakır ve diğerleri, 2017), toplumsal ve kültürel normlardan dolayı kadın yöneticileri bir kabullenmeme durumu söz konusu olmakta ve toplumda okul yöneticilerinin erkek olması yönünde bir alg1 
bulunmaktadır. Kadın, iş ortamında ilişkilerini normal olarak sürdürse bile, mesai harici etkinliklere her zaman katılamamaktadır. Yöneticilerin çoğunun erkek olması ve kadın yöneticilere bakış açılarından dolayı kadın yöneticiler erkeklere kendini anlatmakta zorlanmaktadırlar (Çelikten, 2004). Hutchinson'un (2002) yapmış olduğu araştırmada da, kadın olmalarından kaynaklanan olumsuz düşünceler ve liderlerin erkek olması algısı okul müdürü olmak isteyen kadınların en çok karşılaştı̆̆ı engeller olarak görülmektedir.

Ebeveyn baskısına açık olma, güçlü kadın imajından rahatsızlık ve erkek velilerle iletişim konusu okul öncesi eğitim kurumunda yöneticinin kadın olmasının ebeveyn açısından getirdiği zayıf yönler olarak ortaya çıkmıştır. Beklenilenin üzerinde etkili olan kadın liderler bazı insanların rahatsızlık hissetmesine neden olabilir. Bunun nedeni olarak yöneticilikte erkeklere özgü olarak değerlendirilen davranışları sergilemeleri ve kendilerine toplum tarafından atfedilmiş kadınlık rollerinin dışına çıkmış olmaları söylenebilir (Carli, 2006). Erkek ve kadın arasında etkileşimin olduğu ortamlarda erkek kurallarının sosyal etkileşim içerisinde daha baskın düzeyde yer alması (Özdemir-Yaylacı, 2005) bazı durumlarda iletişim çatışması yaşanmasına neden olabilir.

Kadın yönetici ile çoğunluğu kadın olan okul çalışanlarının kurduğu yakın ilişkilerde iletişim sınırlarının aşılabilmesi, kadın yöneticinin erkek yöneticiyle kıyaslanması ve kadın yöneticinin bazı erkek personel tarafından ciddiye alınmaması hususları okul öncesi eğitim kurumunda yöneticinin kadın olmasının okul personeli açısından getirdiği zayıf yönler olarak ortaya çıkmıştır. Okul öncesi eğitim kurumlarında personel sayısının az olması her ne kadar olumlu bir iletişim iklimi oluştursa da (Büte ve Balcı, 2010) bazı kadın yöneticiler için bu yakınlaşma ve ilişkilerin samimileşmesi, beraberinde farklı sorunları da getirmektedir (Sezer, 2006). Personel sayısı az olduğundan, tüm çalışanların birbirini gereğinden fazla tanıdığı, iletişim ortamının gelişime kapalı hale geldiği, samimiyeti farklı kullananların ve ilişkileri yanlış değerlendirenlerin olabildiği ifade edilmektedir (Büte ve Balcı, 2010). Ayrıca bazı erkek personeller, kadın yöneticiden emir almak istememekte (Çelikersir-Ünal, 2010), göreve yeni başlayan kadın yöneticileri ilk yıllarda benimsememekte, zaman zaman itaatsizlik yapmakta ve dikkate almamaktadırlar (Korkmaz-Moralığlu, 2010). Farklı araştırmalarda ortaya çıkan kadın okul yöneticilerinin iletişim kaynaklı sorunlar yaşadıkları sonucu bu araştırmanın sonucunda da ortaya çıkmıştır.

\section{Okul Öncesi Ĕ̆itim Kurumunda Görev Yapan Kadın Yöneticilerin Yöneticiliği Tercih Etme Nedenleri}

Araştırma sonucunda kadın yöneticilerin yöneticiliği tercih etme nedenlerinin; yönetici olarak çalışmayı isteme, okul öncesi eğitim alanına katkı sağlama düşüncesi, etki alanını genişletme isteği, öğretmenliğin yorucu olması ve yöneticilikte mesleki doyum sağlama düşüncesi gibi daha çok mesleki nedenlerden dolayı tercih ettikleri sonucuna ulaşılmıştır. Bazı yöneticilerse üst yöneticiler tarafindan yönlendirilme yoluyla, lisansüstü eğitim sebebiyle ve yer değiştirme nedeninden dolayı yöneticiliği tercih etmişlerdir. Sezer'in (2006) yapmış olduğu araştırmaya katılan kadın yöneticiler kariyer isteği ve yöneticiliği sevme, yetenek ve karakterine uyması, okul hayatını sevme, öğretmenliği sevmeme, sınıfların kalabalık olması, yöneticileri beğenmeme, başka okula veya yere gitme isteği, sağlık durumu gibi nedenlerden dolayı yöneticiliği tercih ettiklerini belirtmişlerdir. Sezer'in (2006) araştırma sonuçlarıyla bu araştırma sonuçlarının örtüştüğü söylenebilir. Bu araştırmanın sonucunda olduğu gibi Erot'un (2016) araştırmasında da kadın yöneticilerin yarıdan fazlasının kendi istekleriyle yöneticiliği tercih ettikleri belirtilirken, Çelikten (2004) ve Korkmaz-Moralıoğlu'nun (2010) araştırmalarında bazı yöneticilerin yöneticiliğe yönlendirmeyle getirildiklerini belirttikleri ortaya çıkmıştır.

\section{Okul Öncesi Ĕ̆itim Kurumunda Yöneticiliğin Kişiye Sunduğu Avantajlar}

Okul öncesi eğitim kurumunda yöneticiliğin kişiye sunduğu avantajların, mesleki olarak; daha geniş bir açıdan bakabilme, mesleki doyum sağlama, yönetim becerisi kazanma, statü, ilgi alanlarının değişmesi ve güçlü yönleri fark etme, kişisel olarak; mutluluk ve hareketli bir yaşam, sosyal olarak ise; sosyal çevrenin genişlemesi olduğu ortaya çıkmıştır. Kadın yöneticilerin yöneticilikle beraber sosyal çevrelerinin genişlediği, okulla ilgili tüm yönlere daha geniş bir 
açıdan bakabilme firsatı buldukları, yöneticilik sayesinde mesleki doyum sağladıkları ve yöneticilik yapmaktan dolayı mutlu oldukları sonucuna ulaşılmıştır. Okul öncesi eğitim kurumunda yönetici olmanın kişiye daha çok mesleki ve sosyal açıdan avantaj sunduğu söylenebilir. Okul öncesi eğitim kurumu yöneticilerinin iş yaşamlarından aldıkları doyum düzeyleri irdelendiğinde en fazla çalışma ortamlarından doyum aldıkları saptanmıştır. Küçük çocuklarla çalışmanın ve çalışma grubu ile bütünleşmiş olmanın iş doyumu üzerinde etkisi olduğu söylenebilir (Zembat, 1994). Sezer'in (2006) araştırmasına katılan kadın yöneticiler yöneticilikle beraber kişilik özelliklerinde değişiklik olduğu, hayatının daha düzenli bir hal aldığını ve mutlu olduklarını belirtmişlerdir. Yıldırım (2011) yapmış olduğu araştırmada yöneticiliğin okul müdürlerine bireysel katkıları olarak; yöneticilik sayesinde birçok alanda öğrenmenin olması, itibar kazanma, özgüvenin artması, insanları daha iyi tanıma, fiziki olarak daha dikkatli olma ve maddi kazançlarının artması sonuçlarına ulaşmıştır. Yıldırım'ın (2011) araştırmasındaki sonuçlarla bu araştırmanın sonuçları mesleki ve sosyal açılardan örtüşmektedir. Bu kurumlarda yönetici olmanın belirtildiği gibi avantajları mevcuttur ve bu durum yöneticileri mesleki, kişisel ve sosyal açılardan mutlu etmekte ve bunun okula yansıması olumlu olmaktadır. Yıldırım'ın (2011) araştırmasında ortaya çıkan maddi kazancın artmasının bireye katkı yaptığı sonucu bu araştırma sonucunda ortaya çıkmamıştır. Bu araştırmanın katılımcıları olan okul öncesi eğitim kurumu yöneticileri her ne kadar yöneticilikten dolayı aldıkları ek ders ücret artışını bir avantaj olarak belirtmeseler de Milli Eğitim Bakanlığı Yönetici ve Öğretmenlerin Ders ve Ek Ders Saatlerine İlişkin Kararın (2006) 10. Madesinde belirtilen ders niteliğinde yönetim görevi olarak haftalık 25 saat, Kamu Görevlileri Hakem Kurulunun (2012), 29/05/2012 tarih ve 2012/1 Sayılı Kararının 29. Maddesindeki “...örgün ve yaygın eğitim kurumlarındaki yöneticilere ödenmekte olan ek ders ücreti, ikili ögretim yapan örgün eğitim kurumlarındaki yöneticilere ders yıl süresince haftada iki saat arttırımlı ödenir." hükmü gereğincede 2 saat olmak üzere toplamda haftalık 27 saate kadar ek ders ücreti almaktadırlar. Kadın yöneticilerin bu ücret artışını yöneticiliğin sağladığı bir avantaj olarak görmemeleri, bu ücreti zaten hak ettikleri bir ücret olarak görmelerinden kaynaklanıyor olabilir.

\section{Okul Öncesi Ĕ̆itim Kurumunda Yöneticiliğin Kişiye Getirdiği Dezavantajlar}

Okul öncesi eğitim kurumunda yöneticiliğin kişiye getirdiği dezavantajların; mesleki olarak; öğretmenlikten uzaklaşma ve alan dışı işlerle uğraşma, kişisel olarak; aileye zaman ayıramama, özel hayatı kısıtlama ve yorgunluk hissi, sosyal olarak; akraba ve arkadaş çevresinden uzaklaşma olduğu ortaya çıkmıştır. Araştırma bulguları incelendiğinde okul öncesi eğitim kurumunda yönetici olmanın kişiye daha çok kişisel ve sosyal açıdan dezavantaj getirdiği söylenebilir.

Araştırma sonucunda yönetici olarak çalışmanın kadın yöneticilerin kendilerine, ailelerine, akraba ve arkadaş çevresine ayırdıkları zamana kısıtlama getirdiği sonucuna ulaşılmıştır. Birçok araştırmada kadın yöneticilerin, yönetici kimliklerinin aile yaşamlarını etkilediği ve ailelerine yeterli ilgiyi gösteremedikleri sonucuna ulaşılmış ve bu nedenlerin kadınlar için bir kariyer engeli olarak görüldüğü ortaya çıkmıştır (Bayrak ve Mohan, 2001; Can, 2008; Çelikesir-Ünal, 2015; Çelikten, 2004; Evetts, 2000; Gökalp, 2008; Gündüz, 2010; Günsel ve diğerleri, 2015; Korkmaz-Moralığlu, 2010; Sezer, 2006; Usluer, 2000). Ayrıca idareciliğin yorucu olması, yapılmaması gereken bir iş olarak görülmesi, sorumluluğunun fazla olması, kişinin kendine ayıracağı ve ev işlerine ayırdığı zamanı azaltması (Ağıroğlu-Bakır ve diğerleri, 2017; Çelikesir-Ünal, 2015) gibi nedenler kadın yöneticilerin yaşadığı problemler olarak görülmektedir. Yıldırım'ın (2011) yapmış olduğu araştırmada ise yöneticiliğin okul müdürlerine olumsuz katkılarının daha çok sağlık, zaman, mesleki gerileme, aile, psikolojik ve fiziki değişim başlıkları altında toplandığı tespit edilmiştir.

\section{Kadın Yöneticilerinin Müdür Yardımcılarının Erkek Ya da Kadın Olmasına Yönelik Tercihi}

Araştırma sonucunda kadın yöneticilerin tamamına yakınının erkek müdür yardımcılarıyla çalışmayı tercih ettikleri ortaya çıkmıştır. Kadın yöneticilerin erkek yöneticinin ön planda olması gereken durumların bulunması, erkek yöneticinin kuruma farklı bir bakış açısı kazandırması, çalışanlarının tamamına yakını kadın olan okul öncesi eğim kurumlarında erkek yöneticinin 
iletişimde denge sağlaması, kadınların izin ihtiyaçlarının oluşması ve güvenlik nedenlerinden dolayı erkek müdür yardımcısıyla çalışmayı tercih ettikleri sonucuna ulaşılmıştır.

Erkek yöneticiler kişiler arası ilişkilerinde daha mesafeli ve duygusallıktan uzak davranmakta, bütünsel bakış açısına sahip olup, iş yaşamı ile sosyal yaşamlarını birbirinden ayrı tutmaktadır (Özdemir-Yaylacı, 2005). Kadın yöneticilerin, duygusal, hassas, kırılgan ve 1lımlı; erkek yöneticilerin ise otoriter, daha akılcı ve sert bir yöneticilik sergiledikleri, ayrıca erkek yöneticilerin, kadınlara oranla daha atak, daha cesur oldukları, radikal kararları hızlı bir şekilde alabildikleri görülmektedir (Korkmaz-Moralığlu, 2010). Çelikten ve Yeni'ye (2004) göre erkekler olaylar karsısında daha soğukkanlı, örgüte hâkim ve kontrollü şekilde, çalıştıkları örgüte yön veren takım çalışmasını teşvik eden davranışlar gösterirken, formal ve hiyerarşik otoriteyi gözetme, demokratik ve moral etiğe uygun davranma gibi davranışları ile erkeklerde liderlik davranışlarından çok yöneticilik davranışları hâkimdir. Yapılan araştırmalarla bu araştırmanın sonuçları karşılaştırıldığında erkek yöneticilerin gösterdikleri yönetsel davranışlar açısından sonuçların birbirine yakınlık gösterdiği söylenebilir. Bununla birlikte yapılan bazı araştırmalarda üst yöneticiler, mesai haricinde de ulaşabilmek (Tat, 2015) ve kadınların doğum iznine ayrıldığı zamanlarda işlerin aksayacağına dair endişelerden (Korkmaz-Moralıŏlu, 2010; Şahin 2007) dolayı erkek yöneticilerle çalı̧̧mak istedikleri sonucu ortaya çıkmıştır. Bu sonuç ile bu araştırmada ulaşılan "kadınların izin ihtiyaçlarından dolayı kadın yöneticilerin erkek yöneticilerle çalışmayı istemeleri” sonucunun örtüştüğü görülmektedir.

Toplumun kadınlardan ve erkeklerden oluştuğu gerçeğinden yola çıkarak cinsiyetten kaynaklı durumların ayrıştırıcı değil bütünleştirici bir bakış açısıyla değerlendirilmesi gerektiği söylenebilir. Ayrıca bu ve benzer diğer araştırmalarla da ortaya konmuş olan, kadın yöneticinin kuruma sağladığı avantajlar göz önünde bulundurulabilir. Kadınların toplumun yapı taşı olan aile kurumundaki önemli işlevleri göz önüne alındığında bu işlevlerin okul öncesi eğitim kurumlarına da yansıtılmasına imkân sunmak adına kadın yöneticilere uygun çalışma koşullarının oluşturulması noktasında pozitif ayrımcılık yapılabilir.

\section{Kadın Yöneticilerin Yöneticiliğe Devam Edip Etmeme Düşüncesi}

Araştırma sonucunda görüşmeye katılan kadın yöneticilerin tamamının ilerleyen süreçte de yöneticilik görevine devam etmeyi düşündükleri ortaya çıkmıştır. Kadın yöneticilerin; verimli olabilme düşüncesi, yöneticiliği sevme ve öğretmenliğe dönmeme isteğinden dolayı yöneticiliğe devam etmeyi düşündükleri sonucuna ulaşılmıştır. Kadın yöneticilerin daha çok mesleki nedenlerden dolayı yöneticiliğe devam etmeyi istedikleri ve yöneticilik görevinden memnun oldukları söylenebilir. Benzer şekilde Çelikesir-Ünal'ın (2015) araştırmasına katılan kadın yöneticilerin de yöneticilikten memnun oldukları belirlenmiştir.

\section{Öneriler}

1. Araştırma sonucunda bayan velilerin kadın yöneticilerle daha rahat iletişim kurdukları ortaya çıkmıştır. Bayan velilerin okulla olan iletişimlerinin artması için okul öncesi eğitim kurumlarına yönetici görevlendirmelerinde kadın yöneticiler daha öncelikli olarak tercih edilebilir.

2. Kadın yöneticilerin ebeveynler ve okul personeli ile ilgili işaret ettikleri olumsuzlukların çoğunluğunun iletişim kaynaklı durumlar olduğu ortaya çıkmışır. Bu noktada kadın yöneticilere Milli Eğitim Bakanlığınca/İlçe-İl Milli Eğitim Müdürlüklerince insan ilişkileri ve iletişim konularında merkezi ve mahalli kurs, seminer vb. geliştirici etkinlikler düzenlenebilir.

3. Kadın yöneticilerin yöneticilik görevini daha çok mesleki nedenlerden dolayı tercih ettikleri ortaya çıkmıştır. Yönetimle ilgili becerilerinin artması için kadın yöneticilerin hizmetiçi eğitim faaliyetlerine katılmaları sağlanabilir. Kadın yöneticiler lisansüstü öğrenim görmeye teşvik edilebilirler.

4. Kadın yöneticilerin tamamına yakını erkek müdür yardımcısıyla çalışmayı tercih etmiştir. Okul öncesi eğitim kurumlarının sahip olduğu insan ve madde kaynakları birlikte 
değerlendirildiğinde görevlendirilecek müdür veya müdür yardımcısının birinin kadın diğerinin erkek olmasını sağlama yönünde yasal düzenlemeler yapılabilir.

5. $\mathrm{Bu}$ araştırmanın çalışma grubunu okul öncesi eğitim kurumlarında çalışan kadın yöneticiler oluşturmuştur. Başka bir araştırmada bu kurumlarda çalışan erkek müdürlerin, bu kurumlarda görevli müdür yardımcılarının, öğretmenlerin, eğitimci olamayan diğer personelin ve ebeveynlerin görüşlerine de başvurulabilir.

6. Araştırma nitel bir çalışma olup görüşme yoluyla gerçekleştirilmiştir. Bu konuya ilişkin nicel bir çalışma yapılabilir.

\section{Kaynaklar}

Ağıroğlu-Bakır, A., Uğurlu, C. T., Köybaşı, F. ve Özyazıcı, K. (2017). Kadın okul yöneticileri üzerine nitel bir araştırma. Curr Res Educ, 3(1), 1-14.

Akar, A. (2006). Illköğretim okullarında öğretmen algılarına göre yöneticilerin, yöneticilik becerilerinin örgüt iklimine katkısl: Ankara ili örneği (Yayımlanmamış yüksek lisans tezi). Gazi Üniversitesi Eğitim Bilimleri Enstitüsü, Ankara.

Aktaş-Arnas, Y. (2002). Velilerin okul öncesi eğitime ve okul öncesi eğitim kurumlarına yönelik tutumları. Çukurova Üniversitesi Sosyal Bilimler Enstitüsü Dergisi, 10(10), 24-36.

Aktepe, V. (2014). Okul yöneticilerinin seçme ve yetiştirme uygulamalarına yönelik öğretmen ve yönetici görüşleri. Turkish Studies, 9(2), 89-105.

Altınışık, S. (1995). Kadın öğretmenlerin okul müdürü olmasının engelleri. Kuram ve Uygulamada Ë̆itim Yönetimi, 1(3), 333-334.

Asar, R. (2014). Eğitim kurumlarında kadın yöneticilere karşı tutumların değerlendirilmesi (Yayımlanmamış yüksek lisan tezi). Erciyes Üniversitesi Eğitim Bilimleri Enstitüsü, Kayseri.

Başar, H. (1995). Eğitim denetçisi. Ankara: Pegem Yayınları.

Başaran, İ. E. (1996). Ĕ̈itim yönetimi. Ankara: Yargıcı Matbaası.

Baştuğ, Ö. Y. Ö. ve Çelik, B. (2011). İlköğretimde öğretmen, müdür ve müfettişlerin kadın yöneticilere yönelik tutumlar1. Kuram ve Uygulamada Eğitim Yönetimi [Educational Administration: Theory and Practice ], 17(1), 63-76.

Bayrak, S. ve Mohan, Y. (2001). Erkek yöneticilerin çalışma yaşamı ve liderlik davranışları açısından kadın yöneticileri algılama tarzları. Amme İdaresi Dergisi, 34(2), 89-114.

Baytun, İ. D. ve Özerem, A. (2013). Kuzey Kıbrıs Türk Cumhuriyeti'ndeki kadın müdürlerin yönetim algiları. Ĕ̈itim ve Öğretim Araşstırmaları Dergisi, 2(1), 221-230.

Bulut, Y. ve Bakan, İ. (2005). Yönetici ve yöneticilik üzerine Kahramanmaraş kentinde bir araştırma. SÜ IIBBF Sosyal ve Ekonomik Araştırmalar Dergisi, 9, 62-89.

Bursalıoğlu, Z. (2013). Okul yönetiminde yeni yapı ve davranış. Ankara: Pegem Akademi.

Büte, M. ve Balcı, F. A. (2010). Bağımsız anaokulu yöneticilerinin bakış açısından okul yönetimi süreçlerinin işleyişi ve sorunlar [Preschool principals' views on school management processes and related problems]. Kuram ve Uygulamada Eğitim Yönetimi [Educational Administration: Theory and Practice ], 16(4), 485-509.

Byron, K. (2007). Male and female managers' ability to read emotions: relationships with supervisor's performance ratings and subordinates' satisfaction ratings. Journal of Occupational and Organizational Psychology, 80(4), 713-733.

Can, N. (2008). Okul yöneticilerinin yönetimde cinsiyet faktörüne ilişkin görüşleri. Eğitim ve Bilim, 33(147), 35-41.

Can, N. (2013). Eğitimde insan kaynakları yönetimi, N. Can (Yay. haz.), Kuram ve uygulamada eğitim yönetimi içinde (s. 93-126). Ankara: Pegem Akademi.

Carli, L. L. (2006). Gender 1ssues in workplace groups: effects on gender and communication styleon social infuence. M. Baret ve M. J. Davidson (Yay. haz.), Gender at communication at work içinde (s. 69-83). UK: Ashgate Publishing Company.

Cemaloğlu, N. (2005). Türkiye'de okul yöneticisi yetiştirme ve istihdamı: varolan durum, gelecekteki olası gelişmeler ve sorunlar. Gazi Ĕ̈itim Fakültesi Dergisi, 25(2), 249-274. 
Çalık, E., Koşar, S. ve Dağlı, E. (2012). İlköğretim okullarında kadın yöneticilere yönelik öğretmen tutumlarının değerlendirilmesi. Türk Eğitim Bilimleri Dergisi, 10(4), 637-661.

Çelikten, M. ve Yeni, Y. (2004). Okul müdürlerinin liderlik ve yöneticilik özelliklerinin cinsiyet açısından değerlendirilmesi. Gazi Üniversitesi Kastamonu Eğitim Dergisi, 12(2), 305314.

Çelikten, M. (2004). Okul müdürü koltuğundaki kadınlar: Kayseri ili örneği. Erciyes Üniversitesi Sosyal Bilimler Enstitüsü Dergisi, 2, 91-118.

Çelikten, M. (2005). The women principals chair in Turkey. Journal of American Academy of Busines, Cambridge, 6(1), 85-94.

Çelikesir-Ünal, D. (2015). Okul yöneticisi ve ögretmen görüşlerine göre eğitim kurumlarında kadın yöneticiler (Yayımlanmamış yüksek lisans tezi). Erciyes Üniversitesi Eğitim Bilimleri Enstitüsü, Kayseri.

Drucker, F. P. (1995). Yönetim uygulaması, S. Yarmalı (Çev.). İstanbul: İnkılap Kitabevi.

Eagly A. H. ve Johnson, B. T. (1990). Gender and leadership style: a meta-analysis. Erişim adresi: http://digitalcommons.uconn.edu/cgi/viewcontent.cgi?article=1010\&context= chip_docs

Ebabil, D. (2015). Okul öncesi eğitim kurumlarında yönetim süreçlerinin işleyişinin yönetici ve ögretmen görüşlerine göre değerlendirilmesi (Yayımlanmamış yüksek lisans tezi). Çanakkale Onsekiz Mart Üniversitesi Eğitim Bilimleri Enstitüsü, Çanakkale.

Eğitim, İşitsel-Görsel Medya ve Kültür Yürütme Ajansı. (2010). Eğitim çıtktlarında cinsiyet farklıllklarl: Avrupa'da alınan tedbirler mevcut durum. Erişim adresi: http://eacea.ec.europa.eu/education/eurydice/documents/thematic_reports/120 TR.pdf

Erot, B. (2016). Antalya devlet okullarında görev yapan kadın yöneticilerin cam tavan sendromu hakkında görüşlerine ilişkin nitel bir araştırma (Yayınlammamış yüksek lisans tezi). Akdeniz Üniversitesi Eğitim Bilimleri Enstitüsü, Antalya.

Evetts, J. (2000). Analysing change in women's careers: culture, structure and action dimensions. Gender, Work and Organization, 7(1), 57-67.

Foot, H., Howe, C., Cheyne, B., Terras, M. ve Rattray, C. (2000). Pre-school education: Parents' preferences, knowledge and expectations [Enseignement prescolaire: Preferences, connaissances et attentes des parent Educación preescolar: Preferencias, conocimiento y expectativas de los padres.] International Journal of Early Years Education, 8(3), 189204.

Glesne, C. (2013). Nitel araştırmaya giriş, A. Ersoy ve P. Yalçınoğlu (Çev.). Ankara: Anı Yayıncilik.

Gökalp. İ. E. (2008). Türkiye'de kadın girişimciler ve kadın yöneticiler. (Yayımlanmamış yüksek lisans tezi). Kırıkkale Üniversitesi Sosyal Bilimler Enstitüsü, Kırıkkale.

Growe, R. ve Montgomery, P. (2001). Women and the leadership paradigm: bridging the gender gap. Erişim adresi: https://www.researchgate.net/publication/242783132_Women_ and_the_leadership_paradigm_bridging_the_gender_gap

Gündüz, Y. (2010). Öğretmen algılarına göre kadın öğretmenlerin kariyer engellerinin incelenmesi. Abant İzet Baysal Üniversitesi Dergisi, 10(1), 133-149.

Günsel, A., Köroğlu, S. ve Demirci, L. (2015). Çalışma hayatında kadınların karşılaştıkları sorunlar ve cam tavan algıları: kadın öğretmenler üzerinde bir araştırma. Kadın Araştırmaları Dergisi, 1, 73-112.

Hutchinson, S. (2002). The changing world of school administration. G. Perreault ve F. C. Lunenburg (Yay. haz.). Women in school leadership: taking steps to help them make the leap içinde (s. 363-375). United States: NCPEA.

İnandı, Y., Özkan, S., Peker, S. ve Atik, Ü. (2009). Kadın öğretmenlerin kariyer geliştirme engelleri. Mersin Üniversitesi Ĕ̈itim Fakültesi Dergisi, 5(1), 77-96.

İnand1, Y. ve Tunç, B. (2012). Kadın öğretmenlerin kariyer engelleri ile iş doyum düzeyleri arasındaki ilişki. Ë̌itim Bilimleri Araştırmaları Dergisi, 2(2), 203-222.

Kadının Statüsü Genel Müdürlüğü. (2017). Türkiye'de kadın. Erişim adresi: https://kadininstatusu.aile.gov.tr/uygulamalar/turkiyede-kadin 
Kamu Görevlileri Hakem Kurulu Kararı (2012, 29 Mayı). Resmi Gazete. (Sayı: 28310, 01.06.2012. Erişim adresi: http://www.resmigazete.gov.tr

Kaptan, S. (1998). Bilimsel araştırma ve istatistik teknikleri. Ankara: Tekış1k Web Ofset Tesisleri.

Karcı, A. (2012). Yöneticilik yaklaşımında cinsiyet faktörü: Afyonkarahisar ili banka yöneticileri üzerinde bir araştırma (Yayınlammamış yüksek lisans tezi). Afyon Kocatepe Üniversitesi Sosyal Bilimler Enstitüsü, Afyon.

Kertész, R ve Kravetz, H. (2011). Women in management in Argentina. M. Davidson ve R. J. Burke (Yay. haz.), Women in management worldwide, progress and prospects içinde (s. 341-360). Farnham: Ashgate Publishing Ltd.

Korkmaz-Moralığlu, S. (2010). Kamu kurumlarında görev yapan kadın yöneticiler: Kayseri ili örneği. (Yayınlammamış yüksek lisans tezi). Erciyes Üniversitesi Eğitim Bilimleri Enstitüsü, Kayseri.

Lewis P. S., Goodman S. H. ve Fandt, P. M. (1995). Management: challanges in the 21th century. Minneapolis: West Publishing Company.

Lindner, K. (2004). Parental needs and expectations of school-home communication in a child's preparatory year of school. (Unpublished $\mathrm{PhD}$ thesis). University of Melbourne Department of Education, Melbourne.

Milli Eğitim Bakanlığı, (2017a, 22 Nisan). Millî Eğitim Bakanlığına Bağlı Eğitim Kurumlarına Yönetici Görevlendirme Yönetmeliği. Resmi Gazete (Sayı: 30046). Erişim adresi: http://www.resmigazete.gov.tr

Milli Eğitim Bakanlığ (2017b). Milli eğitim istatistikleri, örgün eğitim 1.dönem. Erişim adresi: http://sgb.meb.gov.tr/meb_iys_dosyalar/2017_03/31152628_meb_ istatistikleri_orgun_ egitim_2016_2017_1.pdf

Millî Eğitim Bakanlığı Yönetici ve Öğretmenlerinin Ders ve Ek Ders Saatlerine İlişkin Karar, 01.12. (2006, 16 Aralık). Resmi Gazete (Sayı: 26378) Erişim adresi: http://www.resmigazete.gov.tr

Miles, M. B. ve Huberman, A. M. (1994). Qualitative data analysis: An expanded sourcebook (2th Ed). California: Sage Publications.

Özan-Boydak, M. ve Akpınar, B. (2002). Okul yönetiminde kadın yöneticilerin başarısı. Fırat Üniversitesi Sosyal Bilimler Dergisi, 12(2), 219-234.

Özdemir-Yaylacı, G. (2005). Kadın yöneticiler için kariyer gelişimlerinde örgüt içi 'kişilerarası ilişki ağları'nı yönetmek. İstanbul Üniversitesi İletişsim Fakültesi Dergisi, 23, 213-220.

Özdil-Sağ, G. (2010). Eskişehir ili ilköğretim okulları kadın okul yöneticilerinin kullandıkları güç kaynaklarına göre sergiledikleri liderlik davranışları (Yayınlanmamış yüksek lisans tezi). Ankara Üniversitesi Eğitim Bilimleri Enstitüsü, Ankara.

Öztürk, M. ve Zembat, R. (2015). Okul öncesi yöneticilerinin yaratıcı liderlik özellikleri ile okul iklimi arasındaki ilişkinin incelenmesi. International Journal of Social Science, 31, 455467.

Priola, V. (2007). Being Female doing gender. narratives of women in education management. Gender and Education, 19(1), 21-40.

Sevinç, M. (2006). Okul öncesi eğitimi alan çocukların annelerinin okuldan beklentileri. Kazım Karabekir Eğitim Fakültesi Dergisi, 13, 218-225.

Sezer, S. R. (2006). Üsküdar ilçesindeki okullarda çalışan bazı kadın yöneticilerin mesleklerine ilişskin beklenti ve sorunları (Yayınlanmamış yüksek lisans tezi). Sakarya Üniversitesi Sosyal Bilimler Enstitüsü, Sakarya.

Susmak, M. ve Hacıfazlığlu, Ö. (2013). Öğretmenlerin görüşlerine göre okul öncesi eğitim kurumlarında görev yapan yöneticilerin sahip olması gereken özellikler. Adlyaman Üniversitesi Sosyal Bilimler Enstitüsü Dergisi, 6(13), 205-226.

Şahin, C. (2013). Bir eğitim örgütü olarak okulun yapısı ve işleyişi. N. Can (Ed.), Kuram ve uygulamada eğitim yönetimi (s. 63-92), Ankara: Pegem Akademi.

Şahin, G. (2007). Eğitim örgütlerinde kadın yöneticilerin yeri ve kariyer sorunları (Yayınlanmamış yüksek lisans tezi). Yeditepe Üniversitesi Sosyal Bilimler Enstitüsü, İstanbul. 
Şimşek, Z. C. ve İvrendi, A. (2014). Ebeveynlerin okul öncesi eğitim kurumlarından beklentileri. Hacettepe Üniversitesi Eğitim Fakültesi Dergisi, 29(2), 240-254.

Tat, F. (2015). Kadın yöneticilerle çalışan ögrretmenlerin ve yöneticilerin, kadın yöneticilerin yeterliklerine ilişkin görüşleri (Yayınlanmamış yüksek lisans tezi). Firat Üniversitesi, Eğitim Bilimleri Enstitüsü, Elazı̆̆.

Taymaz, H. (2011). Okul yönetimi. Ankara: Pegem Akademi.

Tunç, A., Ural Uslan, Y. ve Gökçe, A. F. (2015). Türk kamu yönetiminde personel ve yönetici olarak "kadının varlığı": Aile ve Sosyal Politikalar Bakanlığı örneği. G. Ağrıdağ (Yay. haz.). I. Uluslararası Çukurova Kadın Çalışmaları Kongresi bildirileri içinde (s.7-14). Adana: Çukurova Üniversitesi Basımevi.

Turan, S. ve Ebiçlioğlu, N. (2002). Okul müdürlerinin liderlik özelliklerinin cinsiyet açısından değerlendirilmesi. Kuram Ve Uygulamada Eğitim Yönetimi, 8(3), 444-458.

Usluer, L. (2000). Kadın ögretmenlerin yönetici konumlara yükseltilmeme nedenleri konusundaki ögretmen ve yönetici görüşleri: Ankara İli Örneği (Yayınlanmamış yüksek lisans tezi). Ankara Üniversitesi Eğitim Bilimleri Enstitüsü, Ankara.

Vural, Ö. (2008). Okul öncesi eğitim kurumu yöneticilerinin liderlik özellikleri ve empatik becerilerinin incelenmesi (Yayınlanmamış yüksek lisans tezi). Ankara Üniversitesi Fen Bilimleri Enstitüsü, Ankara.

Wu, M. Y. (2006). Perceptions about male and female managers in the taiwanese public relations field: stereotypes and strategies for change, Public Relations Quarterly, 51(3), 36-42.

Yıldırım, N. (2011). Yöneticilik görevinin okul müdürlerine olumlu ve olumsuz katkıları. Eğitim ve Bilim Dergisi, 36(161), 230-245.

Yıldırım, A. ve Şimşek, H. (2013). Sosyal bilimlerde nitel araştırma yöntemleri. Ankara: Seçkin Yayıncilik.

Yiğit, B. (2016). Okul - toplum ilişkileri ve okula toplumsal katılım. V. Çelik (Yay. haz.), Türk eğitim sistemi ve okul yönetimi içinde (s. 199-224). Ankara: Pegem Akademi.

Zembat, R. (1994). Okul öncesi eğitim kurumlarında yönetici özellikleri. Marmara Üniversitesi Atatürk Ĕgitim Fakültesi Ĕgitim Bilimleri Dergisi, 6, 313-323.

\section{Extended Abstract}

\section{Introduction}

Pre-school education institutions are different from other education institutions in structure and functioning. Pre-school education institutions differ from other institutions because their physical characteristics are different from other institutions, age groups of the children are little, the parents especially mothers have a close communication with the school management about their children and expectation from the children, and nearly all of the staff except from the trainers are female. Because of these differences, this kind of education institutions' managements have a different importance. As the ratio of female managers is high, one of the limited areas, the opinions of female managers have a special importance for the management of these institutions. With this in mind, in the research, it has been tried to put forward the views of female managers about themanagement of pre-school education institutions. In this direction, these questions are asked to the female managers working in pre-school education institutions:

1. What are the opinions about whether the manager should be a male or a female at pre-school education institution?

2. What are the opinions about the positive (strong) aspects of female manager at pre-school education institution?

3. What are the opinions about the negative (weak) aspects of female manager at pre-school education institution?

4. What are the views on the reasons for choosing being a manager?

5. What are the views on the benefits of being a manager at a pre-school institution?

6. What are the views on the disadvantages of being a manager at a pre-school institution?

7. What are the views on the choice of the assistant managers to be male or female? 
8. What are the opinions on whether to continue the management or not? These questions are the sub-problems of research.

\section{Method}

The research is a qualitative study and it was carried out in a case study pattern. The study group of the study consisted of 10 female school managers working at independent pre-schools in Kahramanmaraş province center; in Onikişubat and Dulkadiroğlu districts. The research data were obtained through interviews. A semi-structured interview form was used during the interviews. Interviews were conducted at the schools where female managers were working. The data was analyzed by content analysis. The data were separately coded by the investigators. To determine the percentage of agreement between the two investigators' coded, reliability analysis was done and the reliability was found .72 .

\section{Findings and Results}

Half of the female managers who participated in the interview stated that the gender of the manager was not important in the pre-school education institution, while the other half stated that the manager should be female. Field expertise is seen as an important feature that must be possessed in order to be able to manage in preschool education institution, according to managers who think that gender is not important. Those who think that the manager should be women stated that they have motherhood feelings, women are more sensitive and they can communicate more easily with mother parents. It is seen as a powerful feature of women managers at pre-school educational institutions that they are better able to communicate with the children, mother parents and the majority of staff who are female. Women managers stated that they prefer to be managers for more professional reasons, such as the desire to be an manager, the thought to contribure the pre-school process as a manager and for them being a pre-school teacher is so tiring physically and mentally. Nearly all of the women managers who participated in the interviews (9/10) stated that they prefer to work with male manager assistant, and think that they would continue to be a manager.

As a result of the research, it is found that at the pre-school education institution, the female managers' views on the gender of the manager were collected under two headings. Half of the women managers stated that the gender of the manager was not important, while the other half stated that the managers should be women. It is also found that female managers at the preschool education institution have many positive effects for school, children, parents and school staff. Female managers mostly think that these positive effects of being female manager at preschool educational institutions are; regulation of the physical environment, interpersonal relations andcommunication. Another result of the research is that there are some negative effects of being female manager at pre-school educational institutions in terms of school, parents and school staff. It is also seen that these are the weaknesses of female managers; difficulty in following up physical things and suppling physical needs, social prejudice, interpersonal relations and communication-related negativities. The reasons why female managers prefer management are generally for more professional reasons; the desire to be an manager, the thought to contribure the pre-school process as a manager. As an other result of the study, being a female manager at pre-school education institution, there are a number of professional, personal and social advantages such as being able to look at women managers from a wider perspective, being happy and expanding the social environment, as well as there are some disadvantages such as being away from teaching, insufficient time for family members and friends. In additon, approximately all of the female managers prefer to work with male manager assistant and in the following process, they want to continue working as managers.It has been suggested that in order to prevent the disadvantages of only male or only female managers, at pre-school education institutions, one of the manager or manager assistant can be appointed a male, the other is female. At the end of the research, it is also suggested that communication courses, seminars, etc. can be organized for female managers. 